Once you have Acrobat Reader open on your computer, click on the Comment tab at the right of the toolbar:

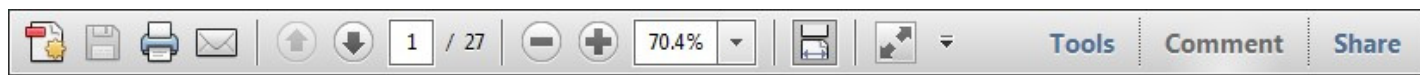

This will open up a panel down the right side of the document. The majority of tools you will use for annotating your proof will be in the Annotations section, pictured opposite. We've picked out some of these tools below:

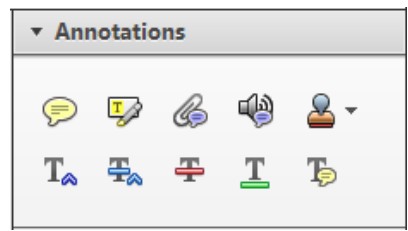

1. Replace (Ins) Tool - for replacing text.

Tistikes a line through text and opens up a text box where replacement text can be entered.

How to use it

- Highlight a word or sentence.

- Click on the Replace (Ins) icon in the Annotations section.

- Type the replacement text into the blue box that appears.

ıdard tramework for the analysis of $\mathrm{m}$ icy-Nevertheless, it also led to exog،

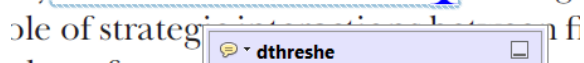
aber of comp 08/06/2011 15:58:17 $\quad$ O is that the $\mathrm{s} 1$, which led of nain compo: be level, are exc nc

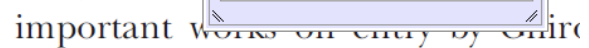
M heneforth) 1 we onen the 'hlarle $\mathrm{t}$

3. Add note to text Tool - for highlighting a section to be changed to bold or italic.

T) Highlights text in yellow and opens up a text box where comments can be entered.

How to use it

- Highlight the relevant section of text.

- Click on the Add note to text icon in the Annotations section.

- Type instruction on what should be changed regarding the text into the yellow box that appears.

namic responses of mark ups ent with the VAR evidence

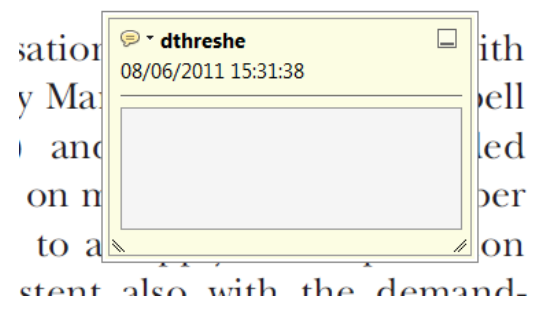

2. Strikethrough (Del) Tool - for deleting text.

T Strikes a red line through text that is to be deleted.

How to use it

- Highlight a word or sentence.

- Click on the Strikethrough (Del) icon in the Annotations section.

there is no room for extra protits al s ups are zero and the number of zet) values are not determined by Blanchard and Kiyotaki (1987), sfect competition in general equilil ts of aggregate demand and supply lassical framework assuming monol een on evorenous number of firme

4. Add sticky note Tool - for making notes at specific points in the text.

Marks a point in the proof where a comment needs to be highlighted.

How to use it

- Click on the Add sticky note icon in the Annotations section.

- Click at the point in the proof where the comment should be inserted.

- Type the comment into the yellow box that appears.

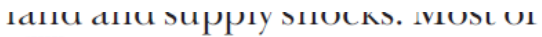

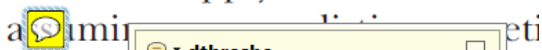

numbe $\mid \begin{aligned} & \ominus \text {-dthreshe } \\ & 08 / 06 / 2011 \text { 15:18:08 }\end{aligned}$

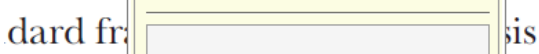

cy. Nev pa

le of st $\square$ wi

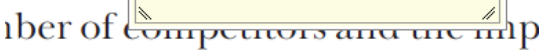

is that the structure of the secto 
5. Attach File Tool - for inserting large amounts of text or replacement figures.

Inserts an icon linking to the attached file in the appropriate place in the text.

\section{How to use it}

- Click on the Attach File icon in the Annotations section.

- Click on the proof to where you'd like the attached file to be linked.

- Select the file to be attached from your computer or network.

- Select the colour and type of icon that will appear in the proof. Click OK.

\section{E N D}

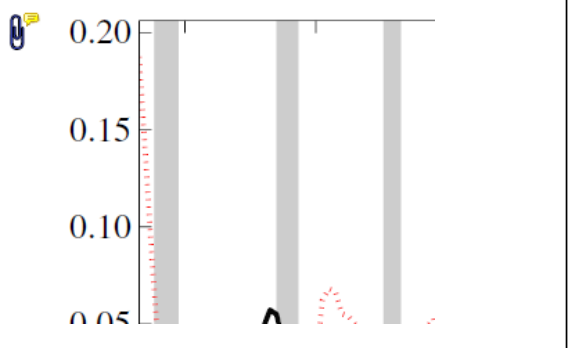

6. Drawing Markups Tools - for drawing shapes, lines and freeform annotations on proofs and commenting on these marks. Allows shapes, lines and freeform annotations to be drawn on proofs and for comment to be made on these marks.

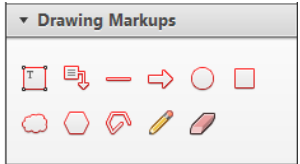

How to use it

- Click on one of the shapes in the Drawing Markups section.

- Click on the proof at the relevant point and draw the selected shape with the cursor.

- To add a comment to the drawn shape, move the cursor over the shape until an arrowhead appears.

- Double click on the shape and type any text in the red box that appears.

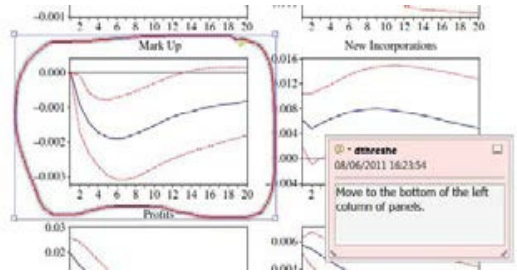




\title{
Carbon and nitrogen allocation and partitioning in traditional 6 and modern wheat genotypes under pre-industrial and future $\mathrm{CO}_{2}$ conditions
}

\author{
S. Aljazairi, C. Arias \& S. Nogués \\ Unitat de Fisiologia Vegetal, Departament de Biologia Vegetal, Universitat de Barcelona, Barcelona, Spain
}

\begin{abstract}
Keywords
Carbon and nitrogen partitioning; climate change; $\mathrm{CO}_{2}$; stable isotopes; Triticum turgidum.
\end{abstract}

\section{Correspondence \\ S. Aljazairi, Unitat de Fisiologia Vegetal, Departament de Biologia Vegetal, Universitat de Barcelona, E-08028 Barcelona, Spain. E-mail: sal337@hotmail.com}

Editor

F. Loreto

Received: 3 July 2014; Accepted: 20 October 2014

doi:10.1111/plb.12280

\begin{abstract}
The results of a simultaneous ${ }^{13} \mathrm{C}$ and ${ }^{15} \mathrm{~N}$ labelling experiment with two different durum wheat cultivars, Blanqueta (a traditional wheat) and Sula (modern), are presented. Plants were grown from the seedling stage in three fully controllable plant growth chambers for one growing season and at three different $\mathrm{CO}_{2}$ levels (i.e. 260, 400 and $700 \mathrm{ppm}$ ). Short-term isotopic labelling (ca. 3 days) was performed at the anthesis stage using ${ }^{13} \mathrm{CO}_{2}$ supplied with the chamber air and ${ }^{15} \mathrm{NH}_{4}{ }^{15} \mathrm{NO}_{3}$ applied with the nutrient solution, thereby making it possible to track the allocation and partitioning of ${ }^{13} \mathrm{C}$ and ${ }^{15} \mathrm{~N}$ in the different plant organs. We found that photosynthesis was up-regulated at pre-industrial $\mathrm{CO}_{2}$ levels, whereas down-regulation occurred under future $\mathrm{CO}_{2}$ conditions. ${ }^{13} \mathrm{C}$ labelling revealed that at pre-industrial $\mathrm{CO}_{2}$ carbon investment by plants was higher in shoots, whereas at future $\mathrm{CO}_{2}$ levels more $\mathrm{C}$ was invested in roots. Furthermore, the modern genotype invested more $\mathrm{C}$ in spikes than did the traditional genotype, which in turn invested more in non-reproductive shoot tissue. ${ }^{15} \mathrm{~N}$ labelling revealed that the modern genotype was better adapted to assimilating $\mathrm{N}$ at higher $\mathrm{CO}_{2}$ levels, whereas the traditional genotype was able to assimilate $\mathrm{N}$ more efficiently at lower $\mathrm{CO}_{2}$ levels.
\end{abstract}

\section{INTRODUCTION}

The rapid increase in the concentration of atmospheric $\mathrm{CO}_{2}$ due to the continued emission of this gas through anthropogenic activities is the main factor driving global climate change. Climate change models predict significant impacts on agriculture, with a decrease in crop yields by 2050 (IPCC 2007, 2013). In particular, climate change is expected to have a slightly larger negative impact on wheat than on other crops, as e.g. potato, maize and rice (IFPRI 2007, 2013).

The concentration of atmospheric $\mathrm{CO}_{2}$ remained stable at $260 \mathrm{ppm}$ for thousands of years prior to the Industrial Revolution, however, since then, $\mathrm{CO}_{2}$ has steadily been accumulating in the atmosphere (Pagani et al. 1999; Pearson \& Palmer 2000). Currently, $\mathrm{CO}_{2}$ concentrations $\left(\left[\mathrm{CO}_{2}\right]\right)$ stand at around 397 ppm (NOAA-ESRL 2014), and atmospheric concentrations continue to rise year after year. Averages of multi-model predictions indicate that by the end of this century atmospheric $\mathrm{CO}_{2}$ will have reached $985 \pm 95 \mathrm{ppm}$ (IPCC 2013). This is expected to result in increases in temperatures (up to $5^{\circ} \mathrm{C}$ ) and more frequent and prolonged periods of drought. Therefore, in order to provide answers as to how plants will adapt to future $\left[\mathrm{CO}_{2}\right]$, it is essential to understand how they have adapted from past to current $\mathrm{CO}_{2}$ levels (Prentice et al. 2001; Sage \& Coleman 2001).

In $\mathrm{C}_{3}$ plants, photosynthesis is usually affected by changes in $\left[\mathrm{CO}_{2}\right]$. Plants undergo a wide variety of changes in response to increases in $\left[\mathrm{CO}_{2}\right]$ and can acclimatise to different atmospheric
$\left[\mathrm{CO}_{2}\right]$ after prolonged periods of exposure (Aranjuelo et al. 2009b, 2011a; Pardo et al. 2009). Photosynthetic acclimation can be defined as the physiological adjustment of plants to a given $\left[\mathrm{CO}_{2}\right]$ where plants undergo increases in photosynthesis at pre-industrial $\left[\mathrm{CO}_{2}\right]$ (up-regulation) and decreases in photosynthesis at future $\left[\mathrm{CO}_{2}\right]$ (down-regulation) through adjustments to the photosynthetic machinery (Nogués \& Azcón-Bieto 2013). These responses can also vary between species or varieties that have physiological or phenological differences, as is true in the case of modern varieties that were selected during the Green Revolution in order to obtain a higher harvest index (HI).

Many studies have shown that photosynthesis is up-regulated in plants subjected to pre-industrial $\mathrm{CO}_{2}$ (Sage \& Reid 1992; Sage 1994; Cowling \& Sage 1998; Anderson et al. 2001). Studies of the effects of pre-industrial $\left[\mathrm{CO}_{2}\right]$ on plants are also fundamental in order to understand plant evolution in response to changes in $\mathrm{CO}_{2}$ resource availability over time (Ward \& Strain 1997; Ward et al. 2000; Gerhart \& Ward 2010). Previous studies carried out in this area suggest that the influence of low $\left[\mathrm{CO}_{2}\right]$ during pre-industrial eras affected plants at many levels, ranging from physiological effects (i.e. photosynthetic acclimation) to changes in the functioning of ecosystems (i.e. the evolution of $\mathrm{C}_{3}$ species; Dippery et al. 1995; Ward et al. $2000)$, and even played a major role in the emergence of agriculture (Gerhart \& Ward 2010).

In short-term experiments (i.e. during only a short part of the plant life cycle), plants have shown increases in photosynthetic 
rate in response to future $\left[\mathrm{CO}_{2}\right]$. However, in experiments with prolonged exposure to future $\left[\mathrm{CO}_{2}\right]$ (over a long period or the entire plant life cycle), in contrast, down-regulation of photosynthesis has been observed (Leakey et al. 2004; Long et al. 2004). One of the parameters that can affect photosynthetic down-regulation is modification of the source-sink ratio (Urban 2003). For example, if increases in carbohydrate production (source) associated with elevated $\left[\mathrm{CO}_{2}\right]$ exceed the capacity of the plant to produce new sinks, net photosynthesis rates may decline in order to balance the source activity with the sink capacity (Thomas \& Strain 1991).

In terms of grain filling in wheat, two types of $C$ source contribute to this process: (i) current photoassimilates are transferred directly to the grain from green tissues (mainly flag leaves and spikes), and (ii) photoassimilates are redistributed from reserve pools to vegetative tissues (leaves, stems and 2 roots; Aranjuelo et al. 2011a). Moreover, the use of photoassimilates is influenced by the genotype and growth conditions, such as stress and/or increases in $\left[\mathrm{CO}_{2}\right]$ (Tambussi et al. 2007; Aranjuelo et al. 2009a,b).

Additionally, nitrogen frequently controls or limits plant growth in many terrestrial ecosystems (Vitousek 1994) and is tightly coupled with the leaf $\mathrm{C}$ cycle (Fisher et al. 2010). The relationship between $\mathrm{C}$ and $\mathrm{N}$ inputs and metabolism are further complicated by the dynamic exchanges between plant organs and the effects of the environment. Therefore, the appropriate balance of $\mathrm{C}$ and $\mathrm{N}$ between sink and source strengths will be an essential objective for maximising the response of cereals to growth under different $\mathrm{C}$ and $\mathrm{N}$ availability conditions (Aranjuelo et al. 2013). With this aim in mind, through the use of stable isotopes, the allocation and partitioning of $\mathrm{C}$ and $\mathrm{N}$ throughout the plant and between organs can be traced and studied. For instance, it was observed that plants at pre-industrial $\left[\mathrm{CO}_{2}\right]$ have stimulated the allocation of $\mathrm{C}$ towards leaves and shoots because of increasing $\mathrm{C}$ demand (Gerhart \& Ward 2010). However, at future $\left[\mathrm{CO}_{2}\right]$ plants can invest more $\mathrm{C}$ in roots due to the increased $\mathrm{C}$ source availability (Ghashghaie \& Tcherkez 2013). Another example is the higher requirement for $\mathrm{N}$ during grain filling in wheat (Fuertes-Mendizábal et al. 2012). $\mathrm{N}$ is remobilised from different parts of the plant (stored before grain filling) or new $\mathrm{N}$ is taken up in the same period (Dupont \& Altenbach 2003). N content in plants is modulated by $\mathrm{CO}_{2}$ and it is lower at future than at current or pre-industrial $\left[\mathrm{CO}_{2}\right]$ (Mitsutoshi et al. 2005). Explanations for this decline in $\mathrm{N}$ content under elevated $\left[\mathrm{CO}_{2}\right]$ include different processes: (i) dilution as a result of higher plant growth, (ii) down-regulation and lower protein content in the form of Rubisco induced by increases in carbohydrate, (iii) limitations in the $\mathrm{N}$ available to plants due to $\mathrm{C}$ enrichment of the rhizosphere, and (iv) inhibition of nitrate assimilation from the soil due to elevated $\left[\mathrm{CO}_{2}\right]$ (Bloom et al. 2014). Understanding the mechanisms controlling whole wheat plant $\mathrm{N}$ and $\mathrm{C}$ isotope composition will further advance our knowledge of the acquisition and allocation of $\mathrm{N}$ and $\mathrm{C}$ in plants under different climate scenarios (Farrar \& Jones 2000; Fisher et al. 2010).

The ${ }^{13} \mathrm{CO}_{2}$ isotope labelling technique was used in this paper to study recently fixed $\mathrm{C}$ in wheat organs and the respiratory metabolism. This allowed calculation of the contribution of stored $\mathrm{C}$ versus current photoassimilates to the production of $\mathrm{CO}_{2}$ through respiration (Schnyder et al. 2003; Nogués et al.
2004, 2014). Labelling with ${ }^{13} \mathrm{CO}_{2}$ permitted us to calculate the proportion of 'new' (i.e. recently fixed) $\mathrm{C}$ in total organic matter (TOM) and respired $\mathrm{CO}_{2}$ (Nogués et al. 2004).

Similarly, the ${ }^{15} \mathrm{NH}_{4^{-}}{ }^{15} \mathrm{NO}_{3}$ isotope labelling technique is used to understand the $\mathrm{N}$ cycle in plants under ambient conditions (Robinson 2001). ${ }^{15} \mathrm{~N}$ can act as a powerful tool to assess whether processes in the $\mathrm{N}$ cycle are influenced by the increasing concentration of atmospheric $\mathrm{CO}_{2}$. The IPCC (2013) predict that with climate change, there will be a reduction in $\mathrm{N}$ availability ( $\mathrm{N}$ limitation) with increasing $\mathrm{CO}_{2}$. A large part of the uncertainly in models predicting climate change feedbacks lies in the role of the $\mathrm{N}$ cycle in modulating the exchange of $\mathrm{CO}_{2}$ between plants, the ecosystem and the atmosphere (Hungate et al. 2003). More importantly, the pattern of changes in plant $\delta^{15} \mathrm{~N}$ in response to future $\left[\mathrm{CO}_{2}\right]$ could guide future studies in identification of the exact processes in the $\mathrm{N}$ cycle that respond to future climate change (BassiriRad et al. 2003).

The main objective of this study was to characterise the $\mathrm{C}$ and $\mathrm{N}$ allocation and its implications in terms of biomass, photosynthesis and reserves in traditional and modern wheat genotypes grown in pre-industrial, current and future $\mathrm{CO}_{2}$ environments. To date, the mechanism conditioning $\mathrm{C}$ and $\mathrm{N}$ allocation responses to pre-industrial $\left[\mathrm{CO}_{2}\right]$ in wheat has not been sufficiently documented, and studying this may help us to understand the behaviour of plants in future climate change scenarios. In order to better understand $\mathrm{C}$ and $\mathrm{N}$ partitioning among the organs of these plants exposed to pre-industrial and future $\left[\mathrm{CO}_{2}\right]_{2}$, double labelling with ${ }^{13} \mathrm{CO}_{2}$ and ${ }^{15} \mathrm{NH}_{4^{-}}{ }^{15} \mathrm{NO}_{3}$ was conducted.

\section{MATERIAL AND METHODS}

\section{Plant material}

Wheat seeds were germinated in Petri dishes. After 4 days, seedlings were transferred to 4-l pots (one plant per pot) filled with quartz sand of $1-\mathrm{mm}$ grain size. Plants were grown in three fully controllable plant growth chambers (Conviron E15; Controlled Environments Ltd, Winnipeg, MB, Canada) at a temperature of $22 / 18{ }^{\circ} \mathrm{C}$ (day/night) and $60 \%$ relative humidity. Plants were supplied with a photosynthetic photon flux density (PPFD) of ca. $400 \mu \mathrm{mol} \cdot \mathrm{m}^{-2} \cdot \mathrm{s}^{-1}$ for a 16 -h light period (day) and the remaining $8 \mathrm{~h}$ in darkness (night). Plants were watered with Hoagland complete nutrient solution. Each plant growth chamber was maintained at a different $\mathrm{CO}_{2}$ level (i.e. 700, 400 and $260 \mathrm{ppm}$ ).

Two durum wheat genotypes (Triticum turgidum var. Sula and var. Blanqueta) were used in the experiment, both of which are cultivated in Spain. Blanqueta is a land race that was widely grown in Sicily and the west of Spain in the first half of the last century, but which is now grown in small areas mainly to satisfy local consumers who appreciate the properties of this variety. It is characterised by its tall stature, high tillering capacity, medium to late heading and maturity, moderate productivity and good adaptability to environments characterised by scarce water and nutrient resources. Sula (released in 1994) is a modern and commercially grown genotype. It is characterised by its short stature, early heading and maturity and high yield potential. It is grown in Andalucía, Catalonia and Extremadura in Spain. 


\section{Experimental design}

The humidity, temperature and $\left[\mathrm{CO}_{2}\right]$ in the chamber air were continuously monitored at 5-min intervals with a combined sensor (CMP3243; Controlled Environments Ltd.) and compared every 2 weeks with separate sensors (HMP75: humidity and temperature, and GMP222: for 0-2000 ppm $\mathrm{CO}_{2}$; Vaisala MI70; Vaisala, Helsinki, Finland) in order to maintain a good characterisation of environmental parameters.

Plants were grown during the whole life cycle (from September to January) under three different levels of $\mathrm{CO}_{2}(700,400$ and $260 \mathrm{ppm}$ ) at the Experimental Fields Service at the University of Barcelona, Barcelona, Spain. Forty-eight plants were placed in the first plant growth chamber and were maintained at a high (future) $\left[\mathrm{CO}_{2}\right]$ (ca. $700 \pm 18 \mathrm{ppm}$ ) during the whole life cycle. In order to raise the $\mathrm{CO}_{2}$ level in the chamber, commercial $\mathrm{CO}_{2}$ (99.5\% pure $\mathrm{CO}_{2}$, without $\mathrm{H}_{2} \mathrm{O}, \mathrm{O}_{2}, \mathrm{~N}_{2}, \mathrm{CO}$ or hydrocarbons) was used (Carburos Metálicos S.A. Barcelona, Spain). An infrared gas analyser (IRGA) connected to the chamber continuously monitored $\mathrm{CO}_{2}$ levels. When the level of $\mathrm{CO}_{2}$ dropped below $700 \mathrm{ppm}$, commercial $\mathrm{CO}_{2}$ was injected into the chamber, thus maintaining $\mathrm{CO}_{2}$ concentration at $700 \mathrm{ppm}$. The air in the three plant growth chambers (future, current and pre-industrial $\mathrm{CO}_{2}$ ) was collected using $10-\mathrm{ml}$ vacutainers and analysed using gas chromatography combustion isotope ratio mass spectrometry (GC/C/IRMS). Mixing of the commercial $\mathrm{CO}_{2}\left(\delta^{13} \mathrm{C}\right.$ ca. $\left.-38.2 \%\right)$ with the ambient air $\left(\delta^{13} \mathrm{C} \quad\right.$ ca. $\left.-12.5 \%\right)$ resulted in a $\delta^{13} \mathrm{C}$ of $\mathrm{CO}_{2}$ of ca. $-22.6 \pm 0.9 \%$ inside the plant growth chamber. Another 48 plants were placed in the second plant growth chamber and were maintained at current $\left[\mathrm{CO}_{2}\right](\mathrm{ca} .400 \pm 20 \mathrm{ppm})$ during the whole life cycle, with a $\delta^{13} \mathrm{C}$ of $\mathrm{CO}_{2}$ of ca. $-11.2 \pm 0.6 \%$. Finally, the same number of plants was placed in the third plant growth chamber and maintained at pre-industrial $\left[\mathrm{CO}_{2}\right]$ (ca. $260 \pm 28 \mathrm{ppm}$ ) during the whole life cycle, with a $\delta^{13} \mathrm{C}$ of $\mathrm{CO}_{2}$ of ca. $-10.8 \pm 0.5 \%$. In this chamber, $\mathrm{CO}_{2}$ was removed using a pump that sent the air inside the chamber through a 1-1 column filled with soda lime (soda lime with indicator QP; Panreac Quimica SA, Barcelona, Spain). The soda lime was changed every 2 weeks. The $\mathrm{CO}_{2}$ levels of these two chambers (400 and $260 \mathrm{ppm}$ ) were also continuously monitored with an
IRGA. Plants were rotated in the plant growth chamber each week to avoid chamber influences in the treatments.

\section{Isotope labelling procedures with ${ }^{13} \mathrm{C}$ and ${ }^{15} \mathrm{~N}$}

Simultaneous $\mathrm{C}$ and $\mathrm{N}$ labelling was conducted in the plants and at different $\mathrm{CO}_{2}$ levels. Double labelling with ${ }^{13} \mathrm{C}$ and ${ }^{15} \mathrm{~N}$ was carried out over 3 days during the anthesis period in order to ensure that both genotypes were labelled with the same amount of ${ }^{13} \mathrm{C}$ and ${ }^{15} \mathrm{~N}$ in the different plant growth chambers. All plants assimilated the same amount of labelled $\mathrm{CO}_{2}$ (ca. $3000 \mathrm{mmol} \mathrm{C} \cdot \mathrm{m}^{-2}$ ) during ca. 3 days, but the assimilation time varied between the different $\mathrm{CO}_{2}$ treatments and was calculated according to their net assimilation rates (Table 1; Nogués et al. 2014).

The ${ }^{13} \mathrm{C}$ composition of air inside the three plant growth chambers was modified during the labelling period. In each of the chambers, mixing of commercial $\mathrm{CO}_{2} \quad\left({ }^{13} \mathrm{C}\right.$ ca. 99.9\%; Euriso-top, Saint-Aubin, France) with the ambient air $\left(\delta^{13} \mathrm{C}\right.$ ca. $-22.6 \%,-11.2 \%$ and $-10.8 \%$ in future, current and pre-industrial plant growth chambers, respectively) resulted in a $\delta^{13} \mathrm{C}$ of $\mathrm{CO}_{2}$ of ca. $165 \%$. Air samples from the chambers and air respired by plants in darkness were taken before and after labelling in order to analyse the ${ }^{13} \mathrm{CO}_{2}$ isotopic composition using GC/C/IRMS according to Nogués et al. (2004).

Labelling with ${ }^{15} \mathrm{~N}$ was also applied during the same period by replacing the ${ }^{14} \mathrm{NH}_{4^{-}}{ }^{14} \mathrm{NO}_{3}$ in the Hoagland solution with double ${ }^{15} \mathrm{~N}$ labelled ammonium nitrate $\left({ }^{15} \mathrm{NH}_{4^{-}}{ }^{15} \mathrm{NO}_{3}\right)$ that had a ${ }^{15} \mathrm{~N}$ excess atom fraction of $5 \%$. After labelling, ${ }^{15} \mathrm{~N}$ was removed by washing the quartz sand with distilled water. Plants were then irrigated with normal Hoagland solution.

\section{Carbon and $\mathrm{N}$ isotope composition of TOM}

Samples from different parts of the plant (i.e. leaves, stems, roots and spikes) were collected before, 1 and 10 days after labelling, dried in an oven at $60{ }^{\circ} \mathrm{C}$ for $48 \mathrm{~h}$ and ground to a fine powder. Then, $1 \mathrm{mg}$ was weighed in tin capsules and $\mathrm{C}$ and $\mathrm{N}$ isotope composition determined using an elemental analyser (Flash EA 112; Carlo Erba, Milan, Italy) coupled to an

Table 1. $\mathrm{CO}_{2}$ effects $(700,400$ and 260 ppm) on physiological parameters in the flag leaf of durum wheat Sula and Blanqueta genotypes.

\begin{tabular}{|c|c|c|c|c|c|c|c|c|c|}
\hline $\mathrm{CO}_{2}$ treatment & Genotype & $V_{c, \max }$ & $J_{\max }$ & $R_{\mathrm{d}}$ & $g_{\mathrm{s}}$ & $A_{\text {sat }}$ & $A_{360}$ & $A_{\max }$ & $C_{i} / C_{a}$ \\
\hline 700 & Sula & $68.9 \pm 5.1$ & $166.4 \pm 4.5$ & $-1 \pm 0.5$ & $22.7 \pm 3.5$ & $15.2 \pm 0.8$ & $19.6 \pm 0.2$ & $28.4 \pm 0.8$ & $0.66 \pm 0.009$ \\
\hline 400 & Sula & $84.2 \pm 15.4$ & $144.3 \pm 30.9$ & $-1.7 \pm 0.9$ & $15.9 \pm 1.7$ & $18.8 \pm 2.4$ & $22.5 \pm 3.1$ & $26.5 \pm 3.7$ & $0.74 \pm 0.008$ \\
\hline 260 & Blanqueta & $88.5 \pm 17.9$ & $181.5 \pm 41.8$ & $-0.7 \pm 0.3$ & $19.1 \pm 0.5$ & $18.4 \pm 4.9$ & $22.7 \pm 5.9$ & $28.7 \pm 4.3$ & $0.62 \pm 0.006$ \\
\hline 260 & Sula & $74.3 \pm 3.6$ & $148.2 \pm 20.3$ & $-1.8 \pm 2.3$ & $15.0 \pm 1.0$ & $18.5 \pm 0.0$ & $22.0 \pm 0.5$ & $26.8 \pm 0.7$ & $0.74 \pm 0.006$ \\
\hline \multicolumn{2}{|l|}{$\mathrm{CO}_{2}$ treatment* $\mathrm{g}$} & n.s. & n.s. & * & * & n.s. & n.s. & n.s. & n.s. \\
\hline
\end{tabular}

$V_{c, \max }=$ maximum carboxylation velocity of Rubisco; $J_{\max }=$ rate of photosynthetic electron transport; $R_{\mathrm{d}}=$ rate of daytime respiration; $g_{\mathrm{s}}=$ stomatal conductance; $A_{\text {sat }}=$ assimilation rate at saturation of light; $A_{360}=$ assimilation rate at $360 \mathrm{ppm} C_{\mathrm{i}}$ of $\mathrm{CO}_{2} ; A_{\text {max }}=$ maximum assimilation rate; $C_{i} / C_{a}=$ internal $C \mathrm{CO}_{2}$ concentration/ambient $\mathrm{CO}_{2}$ ratio.

Data are means $\pm \mathrm{SE}, \mathrm{n}=4$

ANOva Tukey-b (n.s., non-significant; $* P<0.05 ; * * P<0.01 ; * * * P<0.001)$. 
isotope ratio mass spectrometer (Delta C with Conflo III; Thermo Finnigan, Bremen, Germany).

Results of $\mathrm{C}$ isotope ratio analyses are reported as $\delta^{13} \mathrm{C}$ in per mil $(\%)$ and referenced against the international standard V-PDB (Vienna Pee Dee Belemnite) according to the following equation:

$$
\delta^{13} \mathrm{C}(\%)=\left(\frac{\mathrm{R}_{\text {sample }}-\mathrm{R}_{\text {standard }}}{\mathrm{R}_{\text {standard }}}\right) \times 1000
$$

where $\mathrm{R}$ is the ${ }^{13} \mathrm{C} /{ }^{12} \mathrm{C}$ ratio.

Carbon isotope discrimination $\left(\Delta^{13} \mathrm{C}\right)$ was calculated for unlabelled plants from $\delta_{\mathrm{a}}$ and $\delta_{\mathrm{p}}$ (Farquhar et al. 1989) as in the following equation:

$$
\Delta^{13} \mathrm{C}=\frac{\delta_{\mathrm{a}}-\delta_{\mathrm{p}}}{\delta_{\mathrm{p}}+1}
$$

where a and $\mathrm{p}$ refer to $\delta^{13} \mathrm{C}$ of air $\mathrm{CO}_{2}$ and plant material, respectively.

Nitrogen results were also expressed in $\delta^{15} \mathrm{~N}$ notation $(\%)$, using the international secondary standards with known ${ }^{15} \mathrm{~N} /{ }^{14} \mathrm{~N}$ ratio (IAEA $\mathrm{N}_{1}$ and IAEA $\mathrm{N}_{2}$ ammonium sulphate and IAEA $\mathrm{NO}_{3}$ potassium nitrate) with reference to the international primary standard air $\mathrm{N}_{2}$, which has a $\delta^{15} \mathrm{~N}$ value of $0 \%$ (Werner \& Brand 2001):

$$
\delta^{15} \mathrm{~N}(\%)=\left(\frac{\mathrm{R}_{\text {sample }}-\mathrm{R}_{\text {standard }}}{\mathrm{R}_{\text {standard }}}\right) \times 1000
$$

where $\mathrm{R}$ is the ${ }^{15} \mathrm{~N} /{ }^{14} \mathrm{~N}$ ratio.

Labelled samples were expressed in atom fraction (\%) ${ }^{15} \mathrm{~N}$ as recommended in the international guidelines for stable isotope ratio (Coplen 2011).

$$
\text { Atom fraction }(\%)=\frac{\delta+1000}{\delta+1000+\frac{1000}{\mathrm{R}_{\text {standard }}}}
$$

where $\delta$ is the isotopic signature of ${ }^{15} \mathrm{~N}$ samples. $\mathrm{R}_{\text {standard }}$ is the international standard reference.

The $\mathrm{N}$ isotope discrimination $\left(\Delta^{15} \mathrm{~N}\right)$ of TOM for unlabelled plants was calculated from $\delta_{\mathrm{s}}$ and $\delta_{\mathrm{p}}$ (Farquhar et al. 1989) as:

$$
\Delta^{15} \mathrm{~N}=\frac{\delta_{\mathrm{s}}-\delta_{\mathrm{p}}}{\delta_{\mathrm{p}}+1}
$$

where $s$ and $\mathrm{p}$ refer to $\delta^{15} \mathrm{~N}$ of solution and plant, respectively.

\section{Open system for isotopic dark respiration determinations}

The $\delta^{13} \mathrm{C}$ of the $\mathrm{CO}_{2}$ respired after $20 \mathrm{~min}$ in darkness of the different plant organs (i.e. flag leaf, remaining leaves, spikes, stems and root) was studied in a respiration chamber as previously described (Nogués et al. 2004). The chamber was connected in parallel to the sample air hose of a portable gas exchange analyser (Li-Cor 6400; Li-Cor Inc., Lincoln, NE, USA). The PPFD inside the chamber was maintained at $0 \mu \mathrm{mol}$ photon $\cdot \mathrm{m}^{-2} \cdot \mathrm{s}^{-1}$ by covering the chamber with a black piece of, which kept the chamber in darkness. The organ was first placed in the chamber with ambient air $\left(\delta^{13} \mathrm{C}\right.$ ca. $-10.3 \pm 0.5 \%$ o. $)$ The chamber was then flushed with $\mathrm{CO}_{2}$-free air and the $\mathrm{CO}_{2}$ respired by the organ was allowed to accumulate over a period of $10 \mathrm{~min}$. This was then collected using gas syringes (SGE International Pty Ltd, Australia) and stored in $10-\mathrm{ml}$ vacutainers.

The air in the three growth chambers (e.g. pre-industrial, current and future $\mathrm{CO}_{2}$ ) was also sampled using 10 -ml vacutainers in order to obtain isotopic composition of the air (the source of $\mathrm{C}$ ). The $\mathrm{CO}_{2}$ inside the vacutainers was analysed using GC/C/IRMS.

All the GC/C/IRMS and EA/IRMS analyses were performed at the Scientific Technical Services of the University of Barcelona.

\section{Calculation of the proportion (p) of new $\mathrm{C}$ and $\mathrm{N}$}

We assumed that $100 \%$ of $\mathrm{C}$ and $\mathrm{N}$ supplied during short-term labelling could be assimilated by the different parts of the plant, and that this $\mathrm{C}$ and $\mathrm{N}$ is allocated throughout the plant. The proportion of 'new' carbon (derived from the labelling) in $\mathrm{CO}_{2}$ respired in darkness after illumination and the proportion of 'new' $\mathrm{C}$ and $\mathrm{N}$ in TOM was calculated as described in Nogués et al. (2004):

$$
\mathrm{x}=100 \times \frac{\delta_{\text {after }}-\delta_{\text {control }}}{\delta_{\text {fixed }}-\delta_{\text {control }}}
$$

where $\delta_{\text {control }}, \delta_{\text {fixed }}$ and $\delta_{\text {after }}$ are the isotope compositions of the fraction of interest $\left(\mathrm{CO}_{2}\right.$ and TOM) of the control (not labelled), of $\mathrm{C}$ and $\mathrm{N}$ atoms fixed during labelling and of the sample after labelling, respectively. The isotope composition of fixed $\mathrm{C}$ and $\mathrm{N}$ was calculated as:

$$
\delta_{\text {fixed }}=\frac{\delta_{\text {source }}-\Delta}{1+\Delta}
$$

where $\Delta$ is the isotope discrimination (equations 2 and 5) and $\delta_{\text {source }}$ is the isotopic composition of the source during the labelling.

\section{Leaf $\mathrm{C}$ and $\mathrm{N}$ content}

Leaves, spikes, stems and roots used for gas exchange were collected and dried at $65{ }^{\circ} \mathrm{C}$ until constant weight and ground to a powder. An aliquot of $1 \mathrm{mg}$ dry powder was analysed for the $\mathrm{C}$ $\left(\mathrm{mg} \mathrm{C} \mathrm{mg}^{-1}\right)$ and $\mathrm{N}$ content $\left(\mathrm{mg} \mathrm{N}^{\mathrm{mg}} \mathrm{mg}^{-1}\right)$ with an elemental analyser at the Scientific Technical Services at the University of Barcelona, Spain.

\section{Gas exchange analyses}

For simultaneous measurements of gas exchange and chlorophyll fluorescence in an expanded flag leaf, the LI6400 was connected to a leaf chamber fluorometer (LI6400-40). $A / C_{\mathrm{i}}$ curves with chlorophyll fluorescence and dark respiration rates were determined. $A / C_{\mathrm{i}}$ curve determinations were conducted on totally expanded flag leaves for each $\mathrm{CO}_{2}$ treatment and in each genotype. The $A / C_{i}$ curves were repeated in four different 
plants for each treatment and genotype and were measured from 0 to $2000 \mu \mathrm{mol} \cdot \mathrm{mol}^{-1} \mathrm{CO}_{2}$. The curves were generated at $1200 \mu \mathrm{mol}$ photon $\cdot \mathrm{m}^{-2} \cdot \mathrm{s}^{-1} \mathrm{PPFD}$ and $25^{\circ} \mathrm{C}$. Measurements were carried out before anthesis (T0). $\mathrm{CO}_{2}$ assimilation rates $(A), \mathrm{CO}_{2}$ assimilation rate at light saturation $\left(A_{\mathrm{sat}}\right)$, maximum $\mathrm{CO}_{2}$ assimilation rate at $\mathrm{CO}_{2}$ saturation $\left(A_{\max }\right)$ and stomatal conductance $\left(g_{\mathrm{s}}\right)$ were estimated using equations developed by von Caemmerer \& Farquhar (1981). Estimations of the maximum carboxylation velocity of Rubisco $\left(V_{c, \max }\right)$, the rate of photosynthetic electron transport based on NADPH requirement $(J)$ and the rate of respiration $\left(R_{\mathrm{d}}\right)$ were made by fitting a maximum likelihood regression below and above the inflexion of the $A / C_{\mathrm{i}}$ response using the method of Nogués \& Baker (2000).

\section{Biomass parameters}

Biomass parameters in durum wheat genotypes grown at three different $\mathrm{CO}_{2}$ levels (700, 400 and $260 \mathrm{ppm}$ ) were analysed. Leaves were scanned with a commercial scanner (HP ScanJet 3400C; Hewlett-Packard, Palo Alto, CA, USA) and images were analysed with leaf area meter software (Comprises WINDIAS; Delta-T Devices Ltd. Cambridge, UK) to obtain the total leaf area $\left(\mathrm{TLA} ; \mathrm{cm}^{2}\right)$. Harvest index $(\mathrm{HI})$, reproductive biomass (RB; g), shoot dry weight ( shoot DW; g), root dry weight (root DW; g) and shoot/root were also studied. HI was calculated as the ratio between grain DW and total DW.

\section{Data analysis}

The effects of $\mathrm{CO}_{2}$ in both wheat genotypes were tested with two-factor $\left(\mathrm{CO}_{2}\right.$ treatment and durum wheat genotype) ANOVA. The statistical analysis was conducted with SPSS 17.0 software (SPSS Inc., Chicago, IL, USA). The means \pm SE were calculated for each parameter. When a particular test was significant, we compared the means using the Duncan multiple comparison test. The results were accepted as significant at $P<0.05$.

\section{RESULTS}

Before labelling (T0), TOM was more ${ }^{13} \mathrm{C}$-enriched at preindustrial than at current $\left[\mathrm{CO}_{2}\right]$ (with increases of $5.4 \%$ and $7.3 \%$ in spikes, $7.7 \%$ and $6.3 \%$ in leaves, $7.1 \%$ and $8.6 \%$ in stems, $8.7 \%$ and $7.4 \%$ in roots for Blanqueta and Sula, respectively) and more ${ }^{13} \mathrm{C}$-depleted at future $\left[\mathrm{CO}_{2}\right]$ than at current $\left[\mathrm{CO}_{2}\right]$ (with decreases of $9.7 \%$ and $8.2 \%$ in spikes, $6.4 \%$ and $9.5 \%$ in leaves, $8.6 \%$ and $8.6 \%$ in stems, $8.3 \%$ and $9.7 \%$ in roots for Blanqueta and Sula, respectively; Fig. 1, Figure S1). In general, the Blanqueta genotype was between $2.7 \%$ and $5.9 \%$ more ${ }^{13} \mathrm{C}$-enriched than Sula in all organs and $\mathrm{CO}_{2}$ treatments, with some exceptions, e.g. root and stem at elevated $\mathrm{CO}_{2}$. It is worth noting that plants at future $\mathrm{CO}_{2}$ levels were grown with a $\delta^{13} \mathrm{C}$ of ca. $-22.6 \pm 0.9 \%$ inside the plant growth chamber, while the $\delta^{13} \mathrm{C}$ of the other two plant growth chambers were ca. $-10.8 \pm 0.5 \%$ and $-11.2 \pm 0.6 \%$ for 260 and $400 \mathrm{ppm}$, respectively (see Material and Methods).

During labelling, the $\delta^{13} \mathrm{C}$ of the air in the three plant growth chambers was ca. $165 \%$. After labelling (T1), the $\delta^{13} \mathrm{C}$ of TOM in labelled plants was more ${ }^{13} \mathrm{C}$-enriched than the corresponding non-labelled plants in both wheat genotypes (Fig. 1), where spikes were the main $\mathrm{C}$ sink. In general, Blanqueta was more
${ }^{13} \mathrm{C}$-enriched than Sula in all organs and $\mathrm{CO}_{2}$ treatments. However, plants were more ${ }^{13} \mathrm{C}$-depleted at future than at current $\mathrm{CO}_{2}$ conditions and more ${ }^{13} \mathrm{C}$-enriched at pre-industrial than current $\mathrm{CO}_{2}(\mathrm{~F}=23.05, P<0.001)$. We also observed that on the last sampling day (T2), plants were less ${ }^{13} \mathrm{C}$-enriched at higher $\left[\mathrm{CO}_{2}\right]$.

The $\delta^{13} \mathrm{C}$ of respired $\mathrm{CO}_{2}\left(\delta^{13} \mathrm{CO}_{2}\right.$ Respired $)$ in the dark in the different plant organs was analysed with a GC-C-IRMS. It was observed that, ${ }^{13} \mathrm{C}$ losses through dark respiration (Fig. 2) were larger in Blanqueta than in Sula. Although respiration is an important $\mathrm{C}$ sink in all organs, respiration of recently fixed $\mathrm{C}$ was higher in spikes and stems compared to flag and other leaves. Before labelling (T0), $\delta^{13} \mathrm{CO}_{2}$ Respired was ca. $-26 \%$ for leaves, $-26 \%$ for roots, $-30 \%$ (Sula) and $-34 \%$ (Blanqueta) for spikes, and $-34 \%$ for stems in the $700-\mathrm{ppm}$ treatment. In the other $\mathrm{CO}_{2}$ treatments, respired $\mathrm{CO}_{2}$ was more ${ }^{13} \mathrm{C}$-enriched. After labelling (T1), the $\delta^{13} \mathrm{CO}_{2}$ Respired was positive in all organs, indicating that plants had assimilated labelled $\mathrm{C}$, however, the largest quantities were found in spikes and stems. Moreover, the $\delta^{13} \mathrm{CO}_{2}$ Respired values increased with decreasing $\left[\mathrm{CO}_{2}\right]$ (Fig. 2). We also observed that on the last sampling day (T2), the $\delta^{13} \mathrm{CO}_{2}$ Respired was negative once again.

Figure 3 shows a simplified diagram of recently fixed $\mathrm{C}$ and respired $\mathrm{CO}_{2}$ for wheat at 700 (Fig. 3A), 400 (Fig. 3B) and 260 (Fig. 3C) ppm. We assumed that $100 \%$ of $\mathrm{C}$ supplied during short-term labelling could be assimilated by the different parts of the plant, and that this $\mathrm{C}$ was allocated through three main processes: (i) storage in the plant tissues, (ii) translocation to other organs of the plant and (iii) losses through plant respiration.

The percentage of new $\mathrm{C}$ in TOM and $\mathrm{CO}_{2}$ respired after the labelling at $\mathrm{T} 1$ revealed that the $\mathrm{C}$ stored was higher in Blanqueta than in Sula for the different wheat organs and that the spike, followed by leaves, was the organ with the highest percentage of new C; Blanqueta showed double or higher percentage of new $\mathrm{C}$ in pre-industrial $\left[\mathrm{CO}_{2}\right]$, up to seven times more in current $\left[\mathrm{CO}_{2}\right]$ and almost the same value at future $\left[\mathrm{CO}_{2}\right]$ than Sula. However, 10 days after labelling (T2), the percentages of new $\mathrm{C}$ in both varieties decreased. Plants at future $\left[\mathrm{CO}_{2}\right]$ had less new labelled $\mathrm{C}$ than treatments at current $\left[\mathrm{CO}_{2}\right]$, and plants at pre-industrial $\left[\mathrm{CO}_{2}\right]$ had a higher percentage of new $\mathrm{C}$ overall. After labelling, plants exposed to future and pre-industrial $\left[\mathrm{CO}_{2}\right]$ had higher percentages of new $\mathrm{C}$ in respired $\mathrm{CO}_{2}$ than at current $\mathrm{CO}_{2}$ treatments. Interestingly, Sula showed a higher percentage of new respired $\mathrm{C}$ in the different parts of the plant except in the flag (and only at future $\mathrm{CO}_{2}$ ), whereas Blanqueta showed higher percentages than Sula in the other treatments. Figure 3 shows that, in both genotypes, losses of assimilated new $\mathrm{C}$ after the labelling through respiration were between $20-35 \%$ at $700 \mathrm{ppm}$ and $10-30 \%$ at 260 ppm.

Before ${ }^{15} \mathrm{~N}$ labelling (Figure $\mathrm{S} 1$ ), significant differences in $\delta^{15} \mathrm{~N}$ were found between $\mathrm{CO}_{2}$ treatments $(\mathrm{F}=9.61, P<0.05)$, but not between genotypes $(\mathrm{F}=0.527, P=0.471)$. At preindustrial $\left[\mathrm{CO}_{2}\right]$, organs were more ${ }^{15} \mathrm{~N}$-depleted than at current $\left[\mathrm{CO}_{2}\right](0.7 \%$ and $0.5 \%$ in spikes, $0.4 \%$ and $1 \%$ in leaves, $0.6 \%$ and $1 \%$ in stems, $5 \%$ and $4 \%$ in roots) and more ${ }^{15} \mathrm{~N}$-enriched at future $\mathrm{CO}_{2}$ levels than at current $\left[\mathrm{CO}_{2}\right](18 \%$ and $2.7 \%$ in spike, $21 \%$ and $2.2 \%$ in leaves, $14 \%$ and $4 \%$ in stem, $3 \%$ and $2 \%$ in roots, for Blanqueta and Sula, respectively; 

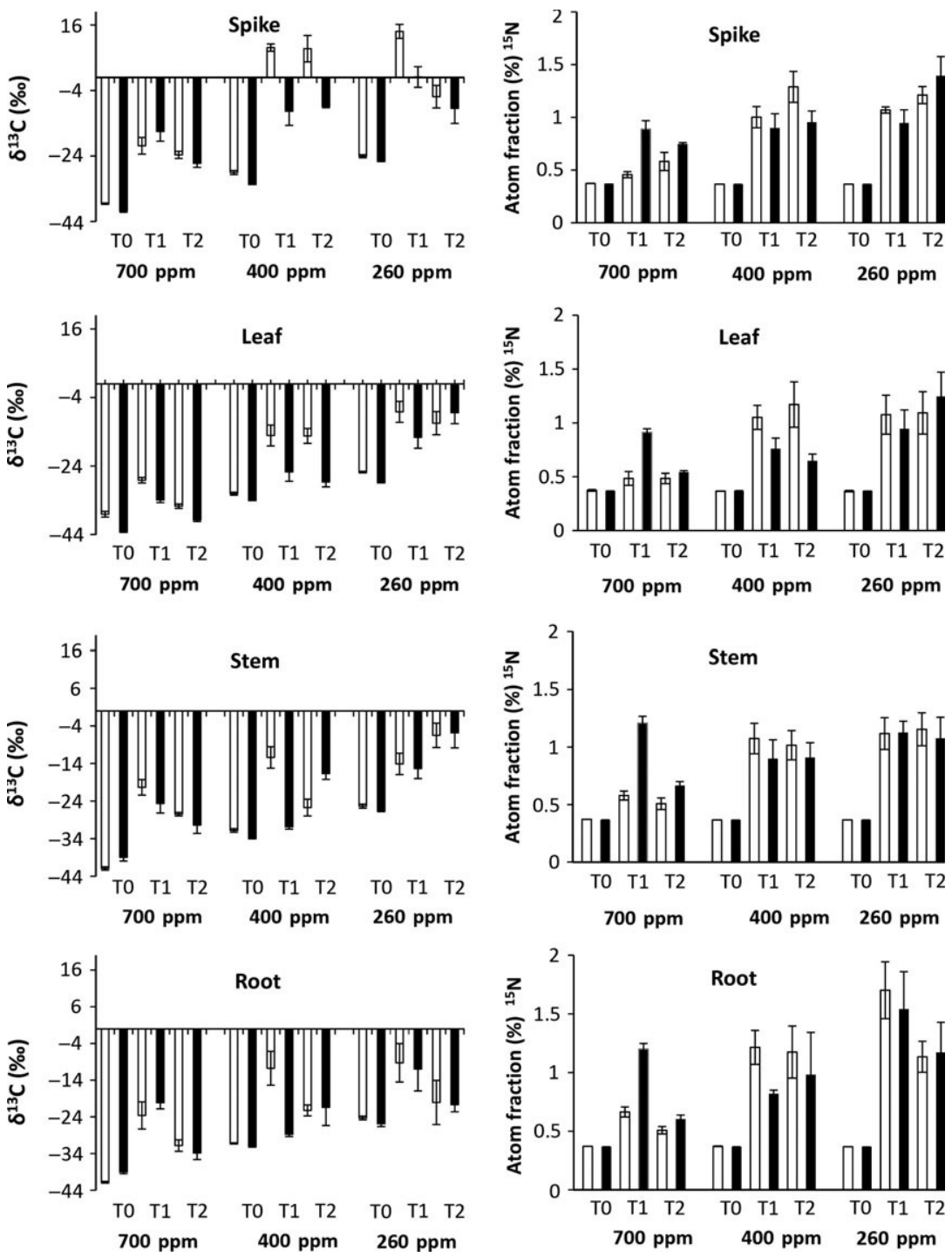

Fig. 1. $\mathrm{CO}_{2}$ effects $(700,400$ and $260 \mathrm{ppm})$ on $\delta^{13} \mathrm{C}(\%)$ and ${ }^{15} \mathrm{~N}$ atomic fraction (\%) values of total organic matter (TOM) in spikes, leaves, stems and roots of two different genotypes of durum wheat: Blanqueta (open bars) and Sula (close bars) before labelling (before anthesis, T0), 1 day after labelling (beginning of grain filling, T1) and 10 days after labelling (end of grain filling, T2). Labelling was made during anthesis. Statistical analysis is presented in Table S1. Data are means $\pm S E, n=4$.

Figure S1). After labelling with ${ }^{15} \mathrm{NH}_{4}{ }^{-1}{ }^{15} \mathrm{NO}_{3}$, at future $\left[\mathrm{CO}_{2}\right]$, Sula had a higher $\delta^{15} \mathrm{~N}$ than Blanqueta. In the other $\mathrm{CO}_{2}$ treatments, Blanqueta was more ${ }^{15} \mathrm{~N}$-enriched. Furthermore, at $260 \mathrm{ppm}$, between labelling and the end of grain filling, spikes and leaves were more ${ }^{15} \mathrm{~N}$-enriched, while roots and stems showed decreases in $\delta^{15} \mathrm{~N}$. In this same period, plants at preindustrial $\left[\mathrm{CO}_{2}\right]$ had more ${ }^{15} \mathrm{~N}$ than plants in current conditions, which in turn were more ${ }^{15} \mathrm{~N}$-enriched than plants at future $\left[\mathrm{CO}_{2}\right]$ (Fig. 1).

The percentage of $\mathrm{N}$ absorbed during the labelling $\left({ }^{15} \mathrm{NH}_{4}\right.$ ${ }^{15} \mathrm{NO}_{3}$ ) was calculated as a percentage of new $\mathrm{N}$ in $\mathrm{T} 1$ and $\mathrm{T} 2$. Overall, the percentage of new $\mathrm{N}$ found in the different plant organs and genotypes ranged from $0.6 \%$ (i.e. spike in Blanqueta at future $\mathrm{CO}_{2}$ ) to $8.8 \%$ (i.e. roots in Blanqueta at pre-industrial $\mathrm{CO}_{2}$; Table 2). Sula presented a higher percentage of new $\mathrm{N}$ in the spike at future $\mathrm{CO}_{2}(3.6 \%)$ than Blanqueta $(0.6 \%)$, whereas Blanqueta presented higher percentages of new $\mathrm{N}$ than Sula in the other treatments $\left(2.8 \%\right.$ and $4.7 \%$ higher at current $\left[\mathrm{CO}_{2}\right]$, $3.6 \%$ and $4.8 \%$ at pre-industrial $\mathrm{CO}_{2}$ in Sula and Blanqueta, respectively). This percentage of new $\mathrm{N}$ was higher in plants growing at lower $\left[\mathrm{CO}_{2}\right]$ in both genotypes. We also found that at T2, percentages were increased in spikes and leaves, since spikes are an important $\mathrm{N}$ sink. Percentage of new $\mathrm{N}$ content decreased in roots as $\mathrm{N}$ was redirected to other organs. In stems, the percentage of new $\mathrm{N}$ decreased at future $\left[\mathrm{CO}_{2}\right]$ since $\mathrm{N}$ was allocated to the leaf or spike where it was used for storage or the production of new proteins and metabolites. This was not the case at pre-industrial $\left[\mathrm{CO}_{2}\right]$, where the percentage of new $\mathrm{N}$ increased in the stem.

All genotypes showed higher leaf and spike $\mathrm{N}$ content $\left(\mathrm{mg} \mathrm{N} \cdot \mathrm{g}^{-1}\right.$ ) at lower $\left[\mathrm{CO}_{2}\right]$ at T0 and T1. However, at T2, leaf $\mathrm{N}$ content was higher at current $\left[\mathrm{CO}_{2}\right]$ than in any other $\mathrm{CO}_{2}$ treatment (Table 3). On the other hand, data was more variable in stems with the lowest $\mathrm{N}$ content at current $\left[\mathrm{CO}_{2}\right]$, at $\mathrm{T} 0$ and 

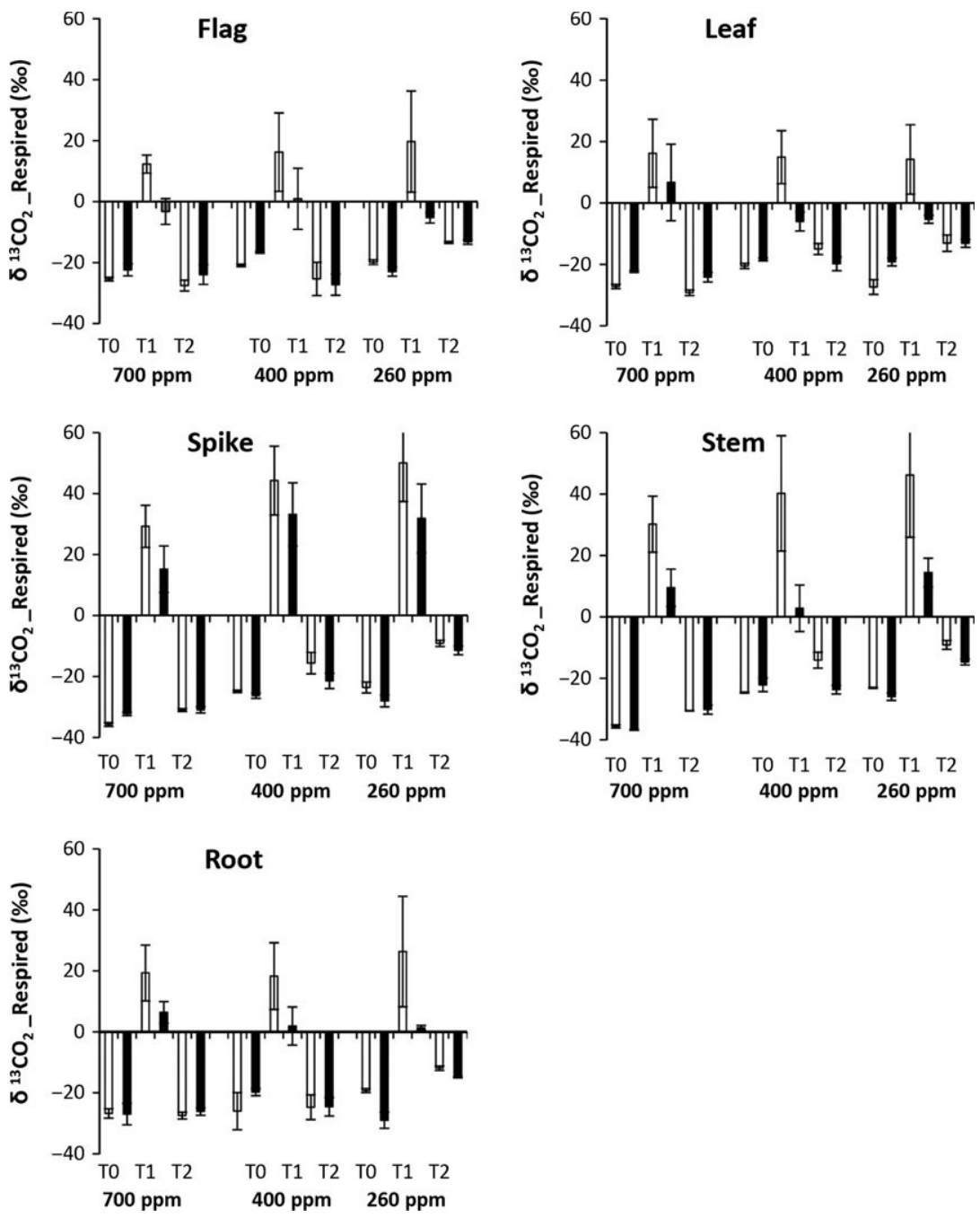

Fig. 2. $\mathrm{CO}_{2}$ effects $(700,400$ and $260 \mathrm{ppm})$ on $\delta^{13}$ values $(\%)$ of respired $\mathrm{CO}_{2}\left(\delta^{13} \mathrm{CO}_{2}\right.$ Respired) in spikes, leaves, stems and roots of two different genotypes of durum wheat: Blanqueta (open bars) and Sula (close bars) before labelling (before anthesis, T0), 1 day after labelling (beginning of grain filling, T1) and 10 days after labelling (end of grain filling, T2). Labelling was made during anthesis. Statistical analysis is presented in Table S1. Data are means $\pm \mathrm{SE}, \mathrm{n}=4$.

$\mathrm{T} 1$ but not at $\mathrm{T} 2$. In roots, the trend was more constant where $\mathrm{N}$ content decreased with higher levels of $\mathrm{CO}_{2}$ for both Sula and Blanqueta genotypes, except for Blanqueta at T2. The relationship between $\delta^{15} \mathrm{~N}$ and $\delta^{13} \mathrm{C}$ in TOM in Sula and Blanqueta genotypes before and after labelling and at the different $\mathrm{CO}_{2}$ levels (700, 400 and $260 \mathrm{ppm}$ ) showed a positive correlation $\left(r^{2}=0.834, P<0.05\right.$; Fig. 4$)$. Table 1 shows that plants underwent an acclimation process under the different $\mathrm{CO}_{2}$ treatments, which can also in part explain $\mathrm{C}$ allocation. At future $\left[\mathrm{CO}_{2}\right]$, we observed that carboxylation activity was diminished by the reduction in $A_{\max }$ and $A_{\text {sat }}$. Furthermore, plants had a lower rate of $V_{c, \max }$ and $J_{\max }$ contributing to RuBP regeneration. $V_{c, \max }, J_{\max }, A_{\mathrm{sat}}, A_{360}$ and $A_{\max }$ increased after prolonged exposure to pre-industrial $\left[\mathrm{CO}_{2}\right]$, although differences between $\mathrm{CO}_{2}$ treatments and genotypes were not significant.

In terms of biomass parameters, significant differences were found between $\mathrm{CO}_{2}$ treatments and genotypes. It was observed that $\mathrm{CO}_{2}$ treatments had a larger effect on the biomass of Sula than Blanqueta (Table 4), although there were no significant differences in TLA between $\mathrm{CO}_{2}$ treatments $(\mathrm{F}=1.872$,
$P>0.05)$ and shoot biomass between genotypes $(\mathrm{F}=2.715$, $P>0.05)$. Shoot DW and root DW were lower at lower $\mathrm{CO}_{2}$ levels. Sula showed higher TLA, spike biomass, shoot and root DW at future $\left[\mathrm{CO}_{2}\right](\mathrm{F}=27.264, P<0.001)$. Higher values in the spike biomass, shoot DW and TLA, and lower values in root DW were found at pre-industrial $\left[\mathrm{CO}_{2}\right]$ compared with current $\left[\mathrm{CO}_{2}\right]$. Finally, Blanqueta had more vegetative and less reproductive biomass than Sula.

\section{DISCUSSION}

In our study, the partitioning and allocation of $\mathrm{C}$ and $\mathrm{N}$ in two wheat genotypes Sula (modern) and Blanqueta (traditional) in three different $\mathrm{CO}_{2}$ treatments were characterized by means of ${ }^{13} \mathrm{C}$ and ${ }^{15} \mathrm{~N}$ labelling.

\section{Photosynthetic acclimation at different $\mathrm{CO}_{2}$ concentrations}

Plant photosynthesis showed acclimation to the different $\mathrm{CO}_{2}$ levels. Currently, photosynthetic acclimation to different 


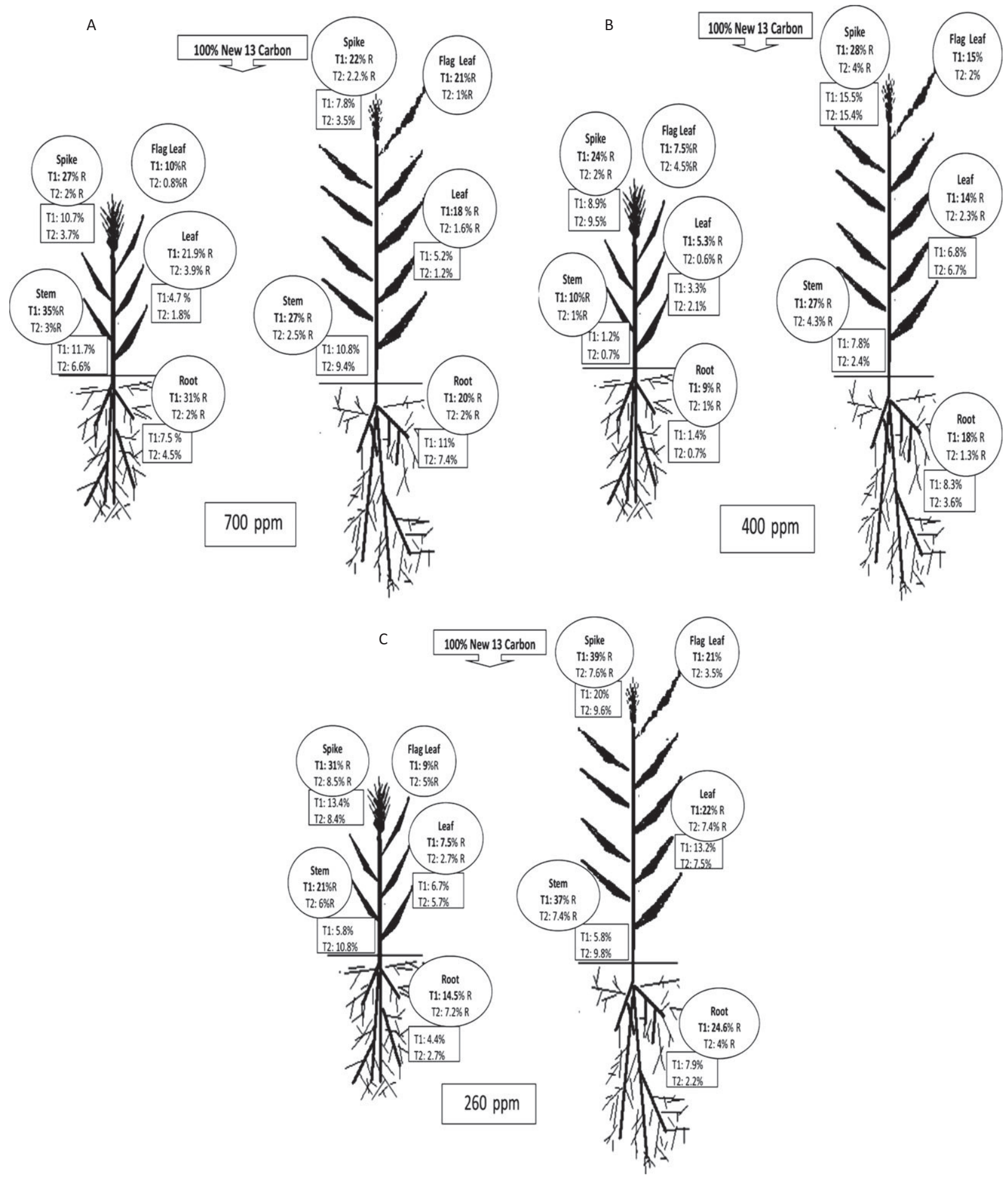

Fig. 3. (A) $\mathrm{CO}_{2}$ effects at 700 ppm on plant $\mathrm{C}$ allocation in spikes, flag leaf, leaves, stems and roots in two genotypes, Sula (left) and Blanqueta (right), 1 day after labelling (beginning of grain filling, $\mathrm{T} 1$ ) and 10 days after labelling (end of grain filling, T2). Labelling was carried out during anthesis with ${ }^{13} \mathrm{CO}_{2}$. Rectangles: \% stored C after labelling. Cloud shapes: \% respired $\mathrm{C}$ after labelling. Sula has small plants and roots, but large spikes. Blanqueta has large shoots and roots but small spikes. Flag leaf total organic matter (TOM) is similar to leaf TOM. (B) $\mathrm{CO}_{2}$ effects at $400 \mathrm{ppm}$ on plant $\mathrm{C}$ allocation in spikes, flag leaf, leaves, stems and roots in two genotypes, Sula (left) and Blanqueta (right), 1 day after labelling (beginning of grain filling, T1) and 10 days after labelling (end of grain filling, T2). (C) $\mathrm{CO}_{2}$ effects at 260 ppm on plant $\mathrm{C}$ allocation in spikes, flag leaf, leaves, stems and roots in two genotypes, Sula (left) and Blanqueta (right), 1 day after labelling (beginning of grain filling, $\mathrm{T} 1$ ) and 10 days after labelling (end of grain filling, T2).

$\mathrm{CO}_{2}$ levels is one of the key issues in $\mathrm{CO}_{2}$ research, and it has been demonstrated that acclimation to pre-industrial and future $\mathrm{CO}_{2}$ during long-term exposure can compensate for the effects of $\mathrm{CO}_{2}$ variation in plant processes (Sage \& Coleman 2001). Plants used in this study, which were maintained at optimal water and nutritional conditions, showed an 
Table 2. $\mathrm{CO}_{2}$ effects $(700,400$ and $260 \mathrm{ppm}$ ) on the percentage of new $\mathrm{N}$ in spikes, leaves, stems and roots in durum wheat Blanqueta and Sula genotypes 1 day (beginning grain filling, T1) and 10 days (end of grain filling, T2) after labelling. Labelling was carried out during the anthesis period.

\begin{tabular}{|c|c|c|c|c|c|c|c|}
\hline $\begin{array}{l}\% \text { New N } \\
\text { Genotype }\end{array}$ & Organ & $\begin{array}{l}700 \\
\mathrm{~T} 1\end{array}$ & $\mathrm{~T} 2$ & $\begin{array}{l}400 \\
\mathrm{~T} 1\end{array}$ & $\mathrm{~T} 2$ & $\begin{array}{l}260 \\
T 1\end{array}$ & $\mathrm{~T} 2$ \\
\hline Blanqueta & Spike & $0.6 \pm 0.2$ & $1.4 \pm 0.6$ & $4.7 \pm 0.8$ & $7.3 \pm 0.2$ & $4.8 \pm 0.3$ & $5.2 \pm 0.2$ \\
\hline Blanqueta & Leaf & $0.7 \pm 0.4$ & $0.7 \pm 0.3$ & $5.4 \pm 0.3$ & $6.9 \pm 0.5$ & $6.5 \pm 0.5$ & $6.1 \pm 1.0$ \\
\hline Sula & Leaf & $3.7 \pm 0.2$ & $1.1 \pm 0.1$ & $2.0 \pm 0.4$ & $1.9 \pm 0.6$ & $3.5 \pm 0.8$ & $4.7 \pm 1.0$ \\
\hline Blanqueta & Stem & $1.4 \pm 0.2$ & $0.9 \pm 0.3$ & $5.5 \pm 0.8$ & $2.6 \pm 0.4$ & $4.9 \pm 1.3$ & $6.3 \pm 0.3$ \\
\hline Sula & Root & $5.7 \pm 0.3$ & $1.6 \pm 0.2$ & $3.1 \pm 0.2$ & $1.7 \pm 0.0$ & $5.5 \pm 0.3$ & $5.5 \pm 1.7$ \\
\hline
\end{tabular}

Data are means $\pm S E, n=4$.

Table 3. $\mathrm{CO}_{2}$ effects $(700,400$ and $260 \mathrm{ppm})$ on $\mathrm{N}$ content $\left(\mathrm{mg} \cdot \mathrm{g}^{-1}\right)$ in leaf, spike, stem and root of durum wheat Blanqueta and Sula genotypes before labeling (before anthesis, T0), 1 day after labeling (beginning of grain filling, T1) and 10 days after labeling (end of grain filling, T2).

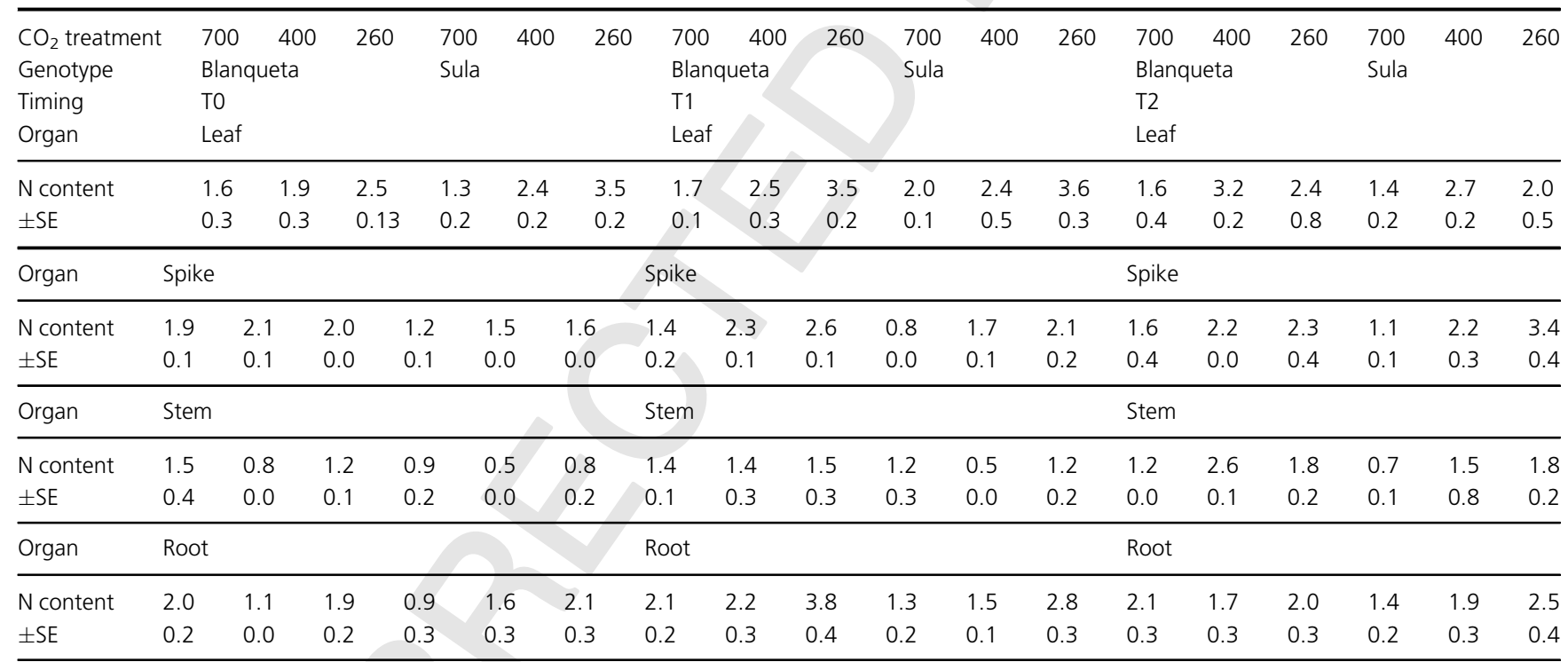

Data are means $\pm S E, n=4$.

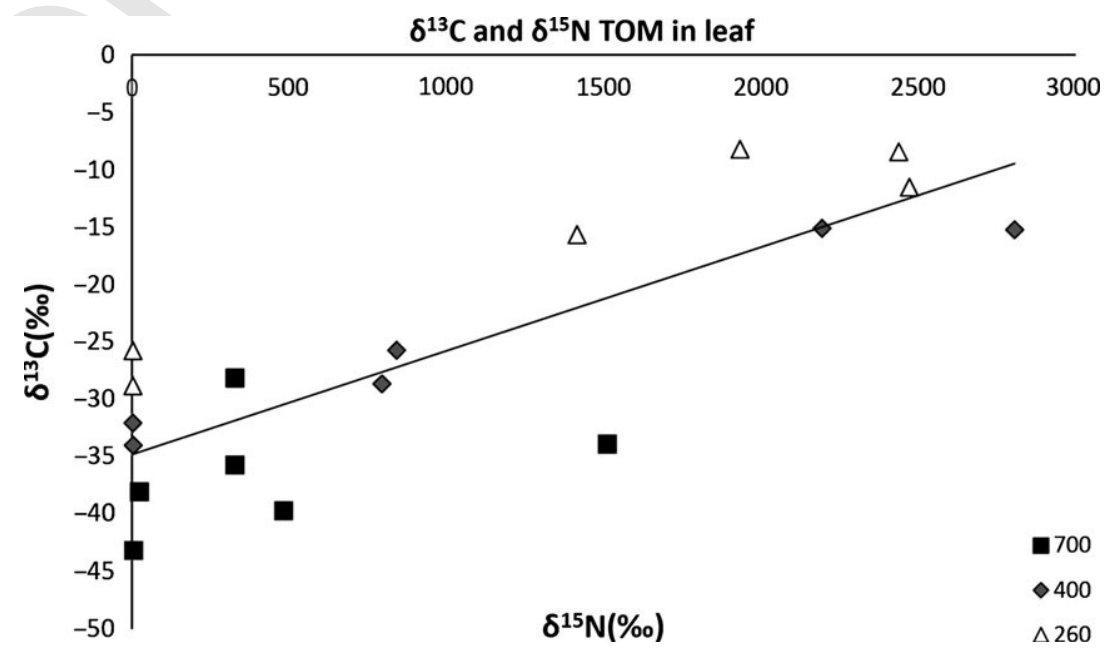

Fig. 4. $\delta^{13} \mathrm{C}$ and $\delta^{15} \mathrm{~N}$ correlation in TOM of the leaf in wheat plants and three $\mathrm{CO}_{2}$ treatments $(700,400$ and 260 ppm), before labelling (before anthesis, T0), 1 day after labelling (beginning of grain filling, T1) and 10 days after labelling (end of grain filling, T2). Labelling was carried out during 3 days in anthesis. Linear regression is significant $\left(r^{2}=0.834 ; P<0.05\right)$. 
Table 4. $\mathrm{CO}_{2}$ effects $(700,400$ and $260 \mathrm{ppm}$ ) on biomass parameters in durum wheat Sula and Blanqueta genotypes at the end of grain filling (T2).

\begin{tabular}{|c|c|c|c|c|c|c|c|}
\hline $\mathrm{CO}_{2}$ treatment & Genotype & TLA & RB & DW shoot & DW root & Shoot/root & $\mathrm{HI}$ \\
\hline 700 & Sula & $95.18 \pm 24.15$ & $13.47 \pm 1.32$ & $7.17 \pm 1.52$ & $3.70 \pm 0.59$ & $1.94 \pm 0.29$ & $0.56 \pm 0.02$ \\
\hline 400 & Sula & $39.30 \pm 5.61$ & $4.75 \pm 1.01$ & $2.57 \pm 0.39$ & $1.13 \pm 0.01$ & $2.27 \pm 0.36$ & $0.54 \pm 0.04$ \\
\hline 260 & Blanqueta & $107.83 \pm 32.48$ & $3.78 \pm 0.72$ & $3.64 \pm 0.50$ & $3.35 \pm 0.65$ & $1.11 \pm 0.05$ & $0.31 \pm 0.02$ \\
\hline 260 & Sula & $52.63 \pm 11.20$ & $5.71 \pm 0.78$ & $3.05 \pm 0.49$ & $0.88 \pm 0.15$ & $3.62 \pm 0.62$ & $0.55 \pm 0.02$ \\
\hline \multicolumn{2}{|c|}{$\mathrm{CO}_{2}$ treatment*genotype } & ** & $\star * *$ & $* * *$ & $* * *$ & * & n.s. \\
\hline
\end{tabular}

TLA = total leaf area $\left(\mathrm{cm}^{2}\right) ; \mathrm{RB}=$ reproductive biomass (g); DW Shoot = shoot dry weight (g); DW Root = root dry weight (g); Shoot/Root; HI = harvest index.

Data are means $\pm S E, n=4$.

ANova Tukey-b (n.s., non-significant, $* P<0.05 ; * * P<0.01 ; * * * P<0.001)$.

up-regulation of photosynthesis with an increase and/or maintenance of physiological parameters such as $V_{\mathrm{c}, \max }, J_{\max }$ and $A_{\text {sat }}$ in response to pre-industrial $\left[\mathrm{CO}_{2}\right]$ (Sage \& Reid 1992; Cowling \& Sage 1998; Anderson et al. 2001). On the other hand, many studies have shown that photosynthesis also acclimates to future $\left[\mathrm{CO}_{2}\right]$ over long-term experiments through down-regulation (Ainsworth et al. 2003; Urban 2003; Long et al. 2004; Aranjuelo et al. 2009b; Pardo et al. 2009) and, consequently, photosynthetic capacity decreases. Here, it was found that $V_{\mathrm{c} \text {, max }}, J_{\max }, A_{\text {sat }}$ and $A_{360}$ (Table 1) were lower at future $\left[\mathrm{CO}_{2}\right]$ than at current levels, clearly indicating a down-regulation of photosynthesis. This implies that significant photosynthetic adjustments (together with increases in $\mathrm{N}$, Rubisco and protein content at pre-industrial $\left[\mathrm{CO}_{2}\right]$ and decreases at future $\left.\left[\mathrm{CO}_{2}\right]\right)$ may have taken place in the past (up-regulation) and will certainly be likely to occur in the future (down-regulation), thereby changing the allocation and balance of $\mathrm{C}$ and $\mathrm{N}$ in plants.

Different plant responses are conditioned by the genetics of the different genotypes (Reynolds et al. 1999) and the availability of $\mathrm{C}$ and $\mathrm{N}$ pools (Fuertes-Mendizabal et al. Q 2010). In our study, traditional genotypes produced more vegetative and less reproductive biomass than did modern genotypes. Plant growth and $\mathrm{C}$ and $\mathrm{N}$ distribution were also modulated by the different $\mathrm{CO}_{2}$ treatments. Sula plants showed a large capacity to increase biomass of the spike and root at future $\left[\mathrm{CO}_{2}\right]$, but less capacity at current or preindustrial $\left[\mathrm{CO}_{2}\right]$ (Aranjuelo et al. 2013). However, in the case of the traditional genotype, vegetative shoots (i.e. leaves and stems) were the main $\mathrm{C}$ and $\mathrm{N}$ sinks. On the other hand, this growth response was associated with increased $\mathrm{C}$ allocation from assimilation areas to the spike, especially when $\mathrm{C}$ was limited, thereby resulting in an increase in the shoot/ root ratio. Lehmeier et al. (2005) found changes in shoot/ root ratios at future and pre-industrial $\left[\mathrm{CO}_{2}\right]$. Optimal $\mathrm{C}$ allocation favours those parts of the plant that incur the most severe growth limitations due to a lack of resources (McConnaughay \& Coleman 1999). In our case, the shoot/ root ratio increased in the Sula genotype with decreasing $\left[\mathrm{CO}_{2}\right]$, from future to pre-industrial $\left[\mathrm{CO}_{2}\right]$ (Table 4). Plants at pre-industrial $\left[\mathrm{CO}_{2}\right]$ may have stimulated $\mathrm{C}$ allocation to shoot organs for grain filling (Anderson et al. 2010). Blanqueta showed a decrease in shoot/root ratio from future to current $\left[\mathrm{CO}_{2}\right]$; however, this effect was not seen at pre- industrial $\left[\mathrm{CO}_{2}\right]$. This could be explained by the fact that (i) the $\mathrm{C}$ requirement of the reproductive shoot area is lower in the traditional genotype than in the modern genotype, and/ or (ii) traditional plants have a bigger vegetative shoot area than Sula (plants were also up-regulated). For this reason, it may be possible that Blanqueta can invest more $\mathrm{C}$ in the root at pre-industrial $\left[\mathrm{CO}_{2}\right]$.

\section{Dynamics of $\mathrm{C}$ and $\mathrm{N}$}

New ${ }^{13} \mathrm{C}$ and ${ }^{15} \mathrm{~N}$ was allocated to all the organs of the plant in both genotypes in the different $\mathrm{CO}_{2}$ treatments. The largest $\mathrm{C}$ sinks were the spike and respiration, since a large percentage of ${ }^{13} \mathrm{C}$ was quickly respired in the first $24 \mathrm{~h}$ after labelling (Tcherkez et al. 2003; Nogués et al. 2004). In our case, 10 days after labelling, plants had lost most ${ }^{13} \mathrm{C}$ through respiration, and a large proportion of the remaining ${ }^{13} \mathrm{C}$ had been allocated to the spike. Plants at future $\left[\mathrm{CO}_{2}\right]$ were less enriched in ${ }^{13} \mathrm{C}$ than at current or pre-industrial conditions because, on the one hand, they were photosynthetically down-regulated and the rate of assimilation was lower, and on the other hand, plants at pre-industrial $\left[\mathrm{CO}_{2}\right]$ discriminated less against $\delta^{13} \mathrm{C}$ because the availability of $\mathrm{CO}_{2}$ was lower than in plants grown at higher levels of $\mathrm{CO}_{2}$ (Farquhar et al. 1989). Thus, $\delta^{13} \mathrm{C}$ in TOM of plant organs increased proportionally with lower $\mathrm{CO}_{2}$ concentrations in the environment.

The percentage of new $\mathrm{C}$ in TOM after the labelling confirmed that $<20 \%$ of $C$ in the different organs, genotypes and treatments was derived from recently assimilated C (Fig. 3; Nogués et al. 2004, 2014; Aranjuelo et al. 2009a). The majority of photoassimilates formed in leaves might be destined for the following processes: (i) respiration, (ii) storage and (iii) export to other tissues (Nogués et al. 2004). However, the photoassimilates in the spike are mainly destined for respiration and storage in the grain. In our case, the traditional genotype fixed more new $\mathrm{C}$ than did the modern genotype, however traditional plants also respired more the new $\mathrm{C}$ and had less new $\mathrm{C}$ fixed in the different organs than did modern plants 10 days after of labelling (T2). This suggests that in modern plants, the spike was the largest $C$ sink, whereas this was respiration in the traditional genotype. $\delta^{13} \mathrm{C}$ increased in leaves and stems at $\mathrm{T} 2$, but decreased in the spike due to respiration and in roots through translocation and respiration. This suggests that at pre-industrial $\left[\mathrm{CO}_{2}\right]$, photoassimilates are stored in stems 
and/or leaves as plants cannot increase the capacity of the spike as a new sink.

Respired $\mathrm{CO}_{2}$ by Blanqueta and Sula (exposed to the three levels of $\mathrm{CO}_{2}$ ) was enriched in ${ }^{13} \mathrm{C}$ at $\mathrm{T} 1$ (Fig. 2), implying that some of the $\mathrm{C}$ assimilated during labelling was immediately respired (Nogués et al. 2014). However, the fact that respired $\mathrm{CO}_{2}$ had low levels of ${ }^{13} \mathrm{C}$ enrichment implies that a large part of the respired $\mathrm{C}$ originated in $\mathrm{C}$ stored in the organs prior to labelling (Fig. 1; Aranjuelo et al. 2009a). C losses through dark respiration were high in the spike and less so in the flag or leaves since these allocated photoassimilate to grain filling (Evans et al. 1975; Schnyder 1993). Ten days after labelling (T2), $\delta^{13} \mathrm{CO}_{2}$ Respired values were similar to those of $\delta^{13} \mathrm{CO}_{2}$ Respired before labelling, suggesting that leaves and other organs had used almost all of the labelled $\mathrm{C}$ substrate. The $\delta^{13} \mathrm{C}$ values of TOM at T1 suggest that plant organs used the labelled $\mathrm{C}$, and the $\delta^{13} \mathrm{C}$ of TOM at T2 shows that some ${ }^{13} \mathrm{C}$ still remained in the plants. After anthesis and during grain filling, the spike had a high demand for photoassimilates, which are supplied by spike photosynthesis and by $\mathrm{C}$ translocation from flag leaves, other leaves and stem internodes (Gebbing \& Schnyder 1999; Tambussi et al. 2007; Aranjuelo et al. 2009a, 2011b). Our data showed that exposure to future $\left[\mathrm{CO}_{2}\right]$ modified the ${ }^{13} \mathrm{C}$ enrichment of respired $\mathrm{CO}_{2}$, as the $\mathrm{CO}_{2}$ used for establishing the $700 \mathrm{ppm}$ atmosphere had an ca. $10 \%$ more negative $\delta^{13} \mathrm{C}$ value, which is also reflected in the respired $\mathrm{CO}_{2}$ of the plants grown at $700 \mathrm{ppm}$, which was lower than at current and pre-industrial $\left[\mathrm{CO}_{2}\right]$ prior to labelling (Fig. 2). However, after labelling, plants exposed to pre-industrial $\left[\mathrm{CO}_{2}\right]$ had higher values of $\delta^{13} \mathrm{C}$ (in TOM and respired $\mathrm{CO}_{2}$ ) and needed more time to lose the enriched ${ }^{13} \mathrm{C}$ in TOM after labelling because in pre-industrial environments plants discriminate less and are more enriched in ${ }^{13} \mathrm{C}$ (Fig. 1) than at current $\left[\mathrm{CO}_{2}\right]$.

Labelled ${ }^{15} \mathrm{~N}$ was applied with the ${ }^{15} \mathrm{NH}_{4}{ }^{-15} \mathrm{NO}_{3}$ of the solution. Spikes and roots were the main $\mathrm{N}$ sinks. Plants were less enriched in ${ }^{15} \mathrm{~N}$ at future $\left[\mathrm{CO}_{2}\right]$ than at pre-industrial $\left[\mathrm{CO}_{2}\right]$ (Fig. 1) as photosynthesis was down-regulated and $\mathrm{N}$ demand was lower. This suggests that acclimation and $\mathrm{CO}_{2}$ treatments also affected the allocation and distribution of $\mathrm{N}$. We found significantly higher levels of leaf $\mathrm{N}$ in both genotypes at preindustrial $\mathrm{CO}_{2}$. Anderson et al. (2001) showed that the up-regulation of assimilation might be related to increases in leaf $\mathrm{N}$ content as well as to the re-allocation of $\mathrm{N}$ within leaves. Moreover, increases in leaf $\mathrm{N}$ and Rubisco would be needed for plants grown at 260 ppm $\mathrm{CO}_{2}$ to achieve a similar level of photosynthetic activity as plants grown at 400 ppm (Sage \& Reid 1992). Cernusak et al. (2011) showed that $\mathrm{N}$ and C content decreased in plants in response to future $\left[\mathrm{CO}_{2}\right]$, as was seen in our study in leaves, spikes and roots for both genotypes, which would provide additional evidence for down-regulation in plants (Figure S2).

After labelling and at future $\left[\mathrm{CO}_{2}\right]$, both genotypes had lower ${ }^{15} \mathrm{~N}$ than at current or pre-industrial $\left[\mathrm{CO}_{2}\right]$ (Fig. 1). However, Blanqueta was more ${ }^{15} \mathrm{~N}$-depleted than Sula at future $\left[\mathrm{CO}_{2}\right]$, whereas in the other $\mathrm{CO}_{2}$ treatments the opposite was true (with Sula being more $\delta^{15} \mathrm{~N}$-depleted). Also, we found different $\delta^{15} \mathrm{~N}$ levels between organs. These data suggest that changes in organ $\delta^{15} \mathrm{~N}$ (i.e. leaves, stems, roots or spikes) can be attributed to internal processes related to the assimilation and loss of ${ }^{15} \mathrm{~N}$ (as, e.g. translocation between organs or root exudates) in the plant and may depend on the genotype and environmental conditions (BassiriRad et al. 2003). Many studies have attempted to explain why there are differences in the $\delta^{15} \mathrm{~N}$ signal between roots and shoots, and between different $\mathrm{CO}_{2}$ levels: (i) changes in the fractionation processes within the plant-mycorrhizal system and/or changes in nitrate assimilation enzymes, which discriminate heavily against ${ }^{15} \mathrm{~N}$ (BassiriRad et al. 2003); (ii) the influence of $C$ availability and soil moisture on microbial activity, thereby enriching plant-available N (Dijkstra \& Cheng 2008); (iii) the correlation between the influence of plant transpiration in the $\mathrm{N}$ acquisition from the soil (Cernusak et al. 2009); and (iv) isotopic fractionations along metabolic reactions (Tcherkez 2010; Gauthier et al. 2013). Furthermore, there is evidence that plant assimilation of nitrate can vary at different $\mathrm{CO}_{2}$ levels (Bloom et al. 2014). In our experiment, we assume a reduction of nitrate assimilation in the shoot under future $\left[\mathrm{CO}_{2}\right]$, in agreement with previous work (Robinson 2001; Kruse et al. 2002). With regard to the percentage of new $\mathrm{N}$, the same pattern was found in plants at future $\left[\mathrm{CO}_{2}\right]$ (i.e. at future $\left[\mathrm{CO}_{2}\right]$ Sula had a higher percentage of new $\mathrm{N}$ than Blanqueta). This suggests that the modern plant (with large $\mathrm{C}$ sinks) at future $\mathrm{CO}_{2}$ conditions will be better adapted to assimilate more $\mathrm{N}$ than traditional plants. However, at current and pre-industrial $\left[\mathrm{CO}_{2}\right]$, traditional plants had higher percentages of new $\mathrm{N}$, suggesting that Blanqueta is better adapted to the assimilation of $\mathrm{N}$ at these levels of $\mathrm{CO}_{2}$.

Furthermore, the correlation between $\delta^{15} \mathrm{~N}$ and $\delta^{13} \mathrm{C}$ $\left(\mathrm{r}^{2}=0.834, P<0.05\right.$; Fig. 4) confirms that the distribution of labelled $\mathrm{C}$ and $\mathrm{N}$ was different between treatments and genotypes, suggesting that the partitioning and allocation of $\mathrm{C}$ and $\mathrm{N}$ was affected both by the genetics of the different genotypes of wheat and the $\mathrm{CO}_{2}$ growth conditions. This allocation is reflected in Figure $\mathrm{S} 2$, where the $\mathrm{N} / \mathrm{C}$ ratio decreases as the overall $\mathrm{CO}_{2}$ increases in leaves, suggesting that at future $\left[\mathrm{CO}_{2}\right]$, leaves are more $\mathrm{N}$ - and $\mathrm{C}$-limited. This is in accordance with Cernusak et al. (2011).

\section{CONCLUSIONS}

The effects of future and pre-industrial $\left[\mathrm{CO}_{2}\right]$, after exposure for a whole growing season, on two genotypes of durum wheat (traditional and modern) were studied. Our data showed, in accordance with photosynthetic parameters, a reduction in net photosynthesis rates and $V_{c, \max }$, at future $\left[\mathrm{CO}_{2}\right]$, indicating a clear down-regulation. Plants showed acclimation at future and pre-industrial $\left[\mathrm{CO}_{2}\right]$, with down- and up-regulation of photosynthesis, respectively. However, at future $\left[\mathrm{CO}_{2}\right]$, this photosynthetic acclimation was disrupted when a new $\mathrm{C}$ sink appeared during grain filling. The pre-industrial $\mathrm{CO}_{2}$ treatment decreased growth and biomass production in both genotypes; however, these effects decreased over time, demonstrating a clear up-regulation of photosynthesis. Also, Blanqueta and Sula modulated the assimilation of ${ }^{13} \mathrm{C}$ in accordance with $\mathrm{CO}_{2}$ level, i.e. plants were less enriched in ${ }^{13} \mathrm{C}$ at future $\left[\mathrm{CO}_{2}\right]$ and more enriched in ${ }^{13} \mathrm{C}$ at pre-industrial $\left[\mathrm{CO}_{2}\right]$.

In our study, we observed the importance of the sink in terms of the response of plants to different $\mathrm{CO}_{2}$ scenarios. Plants invested more $\mathrm{C}$ in shoots than roots at pre-industrial $\left[\mathrm{CO}_{2}\right]$, and specifically, in the case of the traditional genotype, vegetative parts were seen to be the main $\mathrm{C}$ sink. At current and future $\left[\mathrm{CO}_{2}\right]$, the source of $\mathrm{C}$ is higher and plants can redirect more from assimilation compartments (shoots) towards 
non-assimilation compartments (roots). However, at future $\left[\mathrm{CO}_{2}\right]$, it is the modern genotype that has a larger capacity to increase the size of reproductive organs and harvest index. In future studies, it will be necessary to examine the interactions between varying $\mathrm{CO}_{2}$ concentrations and other environmental factors (e.g. drought), as this will allow us to better understand and predict plant processes and the allocation of $\mathrm{C}$ and $\mathrm{N}$ in response to increases in anthropogenic $\left[\mathrm{CO}_{2}\right]$.

\section{ACKNOWLEDGEMENTS}

This study was supported by Ministerio de Educación y Ciencia de España research project (CGL2009-13079-C02-02). SA acknowledges the financial support of Ministerio de Educación y Ciencia de España (BES-2010-032433).

\section{SUPPORTING INFORMATION}

Additional Supporting Information may be found in the online version of this article:
Figure S1. Effects of three different $\mathrm{CO}_{2}$ treatments $\left(700 \mathrm{ppm}, \quad \delta^{13} \mathrm{CO}_{2 \_ \text {air }}-22.6 \% ; \quad 400 \mathrm{ppm}, \quad \delta^{13} \mathrm{CO}_{2 \_ \text {air }}\right.$ $-11.2 \%$ and $260 \mathrm{ppm} \delta^{13} \mathrm{CO}_{2}$ air $-10.8 \%$ o ) on the natural abundance of $\delta^{13} \mathrm{C}$ and $\delta^{15} \mathrm{~N}$ in total organic matter (TOM) of flag leaf, other leaves, spikes, stems and roots in two different genotypes of durum wheat: Blanqueta (open bars) and Sula (close bars).

Figure S2. $\mathrm{CO}_{2}$ effects $(700,400$ and $260 \mathrm{ppm})$ on C and N content $\left(\mathrm{mg} \cdot \mathrm{mg}^{-1}\right)$ in spikes, leaves, stems and roots of durum wheat.

Table S1. Statistical analysis of $\mathrm{CO}_{2}$ effects $(700,400$ and $260 \mathrm{ppm})$ on $\delta^{13} \mathrm{C}(\%)$ and atom $\%{ }^{15} \mathrm{~N}$ values of total organic matter (TOM) in spikes, leaves, stems and roots of two different genotypes of durum wheat: Blanqueta (open bars) and Sula (close bars) before labelling (before anthesis, T0), 1 day after labelling (beginning of grain filling, T1) and 10 days after labelling (end of grain filling, T2).

\section{REFERENCES}

Ainsworth E.A., Dave P.A., Hymus G.J. (2003) Is stimulation of leaf photosynthesis by elevated $\mathrm{CO}_{2}$ maintained in the long term? A test with Lolium perenne grown for 10 years at two nitrogen fertilization levels under free-air $\mathrm{CO}_{2}$ enrichment (FACE). Plant, Cell and Environment, 26, 705-714.

Anderson L.J., Maheraly H., Johnson H.B., Polley H.W., Jackson R.B. (2001) Gas exchange and photosynthetic acclimation over subambient to elevated $\mathrm{CO}_{2}$ in a $\mathrm{C}_{3}-\mathrm{C}_{4}$ grassland. Global Change Biology, 7 , 693-707.

Anderson L.J., Derner J.D., Polley H.W., Gordon W.S., Eissenstat D.M., Jackson R.B. (2010) Root responses along a subambient to elevated $\mathrm{CO}_{2}$ gradient in a $\mathrm{C}_{3}-\mathrm{C}_{4}$ grassland. Global Change Biology, 16, 454-468.

Aranjuelo I., Cabrera Bosquet L., Mottaleb S.A., Araus J.L., Nogués S. (2009a) ${ }^{13} \mathrm{C} /{ }^{12} \mathrm{C}$ isotope labelling to study carbon partitioned and dark respiration in cereals subjected to water stress. Rapid Communications in Mass Spectrometry, 23, 2819-2828.

Aranjuelo I., Pardo A., Biel C., Save R., Azcón-Bieto J., Nogués S. (2009b) Leaf carbon management in slow-growing plants exposed to elevated $\mathrm{CO}_{2}$. Global Change Biology, 15, 97-109.

Aranjuelo I., Morcuende R., Avice J.C., Nogués S., Araus J.L., Martínez-Carrasco R., Pérez P. (2011a) Does ear carbon sink strength contributes to overcoming photosynthetic acclimation of wheat plants exposed to elevated $\mathrm{CO}_{2}$ ? Journal of Experimental Botany, 62, 3957-3969.

Aranjuelo I., Ebbets A., Evans R.D., Tissue D.T., Nogués S., Gestel N., Payton P., Ebbert V., Adams W.W. III, Nowak R.S., Smith S.D. (2011b) Maintenance of $\mathrm{C}$ sinks enhanced $\mathrm{C}$ assimilation during long-term exposure to elevated $\left[\mathrm{CO}_{2}\right]$ in Mojave desert shrubs. Oecologia, 167, 339-354.

Aranjuelo I., Sanz-Saez A., Jauregui I., Irigoyen J.J., Araus J.L., Sanchez-Diaz M., Erice G. (2013) Harvest Index, a parameter conditioning responsiveness of wheat plants to elevated $\mathrm{CO}_{2}$. Journal of Experimental Botany, 64, 1879-1892.

BassiriRad H., Constable J.V.H., Lussenhop J., Kimball B.A., Norby R.J., Oechel W.C., Reich P.B., Schlesing- er W.H., Zitzer S., Sehtiya H.L., Silim S. (2003) Widespread foliage $\delta^{15} \mathrm{~N}$ depletion under elevated $\mathrm{CO}_{2}$ : inferences for the nitrogen cycle. Global Change Biology, 9, 1582-1590.

Bloom A.J., Burger M., Kimball B.A., Pinter P.J. (2014) Nitrate assimilation is inhibited by elevated $\mathrm{CO}_{2}$ in field-grown wheat. Nature Climate Change, 4, 437440 .

von Caemmerer S., Farquhar G.F. (1981) Some relationships between the biochemistry of photosynthesis and the gas exchange of leaves. Planta, 153, 376387.

Cernusak L., Tcherkez G., Keitel C., Cornwell W.K., Santiago L.S., Knohl A., Barbour M., Williams D.G., Reichl P.B., Ellsworth J.D.S., Dawson T.E., Griffiths H.G., Farquhar G.D., Wright I.J. (2009) Why are non-photosynthetic tissues generally ${ }^{13} \mathrm{C}$ enriched compared with leaves in $\mathrm{C}_{3}$ plants? Review and synthesis of current hypotheses. Functional Plant Biology, 36, 199-213.

Cernusak L.A., Winter K., Martinez C., Correa E., Aranda J., Garcia M., Jaramillo C., Turner B.L. (2011) Responses of legume versus non-legume tropical tree seedlings to elevated $\mathrm{CO}_{2}$ concentration. Plant Physiology, 157, 372-385.

Coplen T.B. (2011) Guidelines and recommended terms for expression of stable-isotope-ratio and gasratio measurement results. Rapid Communications in Mass Spectrometry, 25, 2538-2560.

Cowling S.A., Sage R.F. (1998) Interactive effects of low atmospheric $\mathrm{CO}_{2}$ and elevated temperature on growth, photosynthesis and respiration in Phaseolus vulgaris. Plant, Cell and Environment, 21, 427-435.

Dijkstra F.A., Cheng W. (2008) Increased soil moisture content increases plant $\mathrm{N}$ uptake and the abundance of ${ }^{15} \mathrm{~N}$ in plant biomass. Plant and Soil, 302, 263-271.

Dippery J.K., Tissue D.T., Thomas R.B., Strain B.R. (1995) Effects of low $\mathrm{CO}_{2}$ on $\mathrm{C}_{3}$ and $\mathrm{C}_{4}$ annuals $\mathrm{I}$. Growth and biomass allocation. Oecologia, 101, 1320.

Dupont F.M., Altenbach S.B. (2003) Molecular and biochemical impacts of environmental factors on wheat grain development and protein synthesis. Journal of Cereal Science, 38, 133-146.

Evans L.T., Wardlaw I.F., Fischer R.A. (1975) Wheat. In: Evans L.T. (Ed.), Crop physiology: some case histo- ries. Cambridge University Press, Cambridge, UK, pp 101-105.

Farquhar G.D., Ehleringer J.R., Hubick K.T. (1989) Carbon isotope discrimination and photosynthesis. Annual Review of Plant Physiology and Plant Molecular Biology, 40, 503-537.

Farrar J.F., Jones D.L. (2000) The control of carbon acquisition by roots. New Phytologist, 147, 43-53.

Fisher J.B., Stich S., Malhi Y., Fisher R.A., Huntingford C., Tan S.-Y. (2010) Carbon cost of plant nitrogen acquisition: a mechanistic, globally applicable model of plant nitrogen uptake, retranslocation, and fixation. Global Biogeochemical Cycles, 22, GB1014.

Fuertes-Mendizábal T., González-Murua C., GonzálezMoro M.B., Estavillo J.M. (2012) Late nitrogen fertilization affects carbohydrates mobilization in wheat. Journal of Plant Nutrition and Soil Science, 173, 907-919.

Gauthier P.P.G., Lamothe M., Mahé A., Molero G., Nogués S., Hodges M., Tcherkez G. (2013) Metabolic origin of $\delta^{15} \mathrm{~N}$ values in nitrogenous compounds from Brassica napus L. leaves. Plant, Cell and Environment, 36, 128-137.

Gebbing T., Schnyder H. (1999) Pre-anthesis reserve utilization for protein and carbohydrate synthesis in grains of wheat. Plant Physiology, 121, 871-878.

Gerhart L.M., Ward J.K. (2010) Plant Responses to low $\left[\mathrm{CO}_{2}\right]$ of the past. Tansley Review. New Phytologist, 188, 674-695.

Ghashghaie J., Tcherkez G. (2013) Isotope ratio mass spectrometry technique to follow plant metabolism: principles and applications of ${ }^{12} \mathrm{C} /{ }^{13} \mathrm{C}$ isotopes. Advances in Botanical Research, 67, 377-408.

Hungate B.A., Dukes J.S., Shaw M.R., Luo Y., Field C.B. (2003) Nitrogen and climate change. Science, 302, 1512-1513.

IFPRI (2007) International Food Policy Research Institute. Annual report 2007. IFPRI, Washington, DC, USA. ISBN 978-0-89629-920-7.

IFPRI (2013) IFPRI strategy 2013-2018: food policy research in a time of unprecedented challenges. IFPRI, Washington, DC, USA. ISBN 978-0-89629815-6.

IPCC (2007) Climate change 2007: working group I: the physical science basis. Intergovernmental Panel on 
Climate Change, Working group 1, Geneva, Switzerland.

IPCC (2013) Fifth assessment report on climate change 2013: the physical science basis, final draft underlying scientific-technical assessment. Intergovernmental Panel on Climate Change, Working group 1, Geneva, Switzerland.

Kruse J., Hetzger I., Hänsch R. (2002) Elevated $\mathrm{pCO}_{2}$ favours nitrate reduction in the roots of wild-type tobacco (Nicotiana tabacum cv. Gat) and significantly alters $\mathrm{N}$-metabolism in transformants lacking functional nitrate reductase in the roots. Journal of Experimental Botany, 53, 2351-2367.

Leakey A.D.B., Bernacchi C.J., Dohleman F.G., Ort D.R., Long S.P. (2004) Will photosynthesis of maize (Zea mays) in the US Corn Belt increase in future $\left[\mathrm{CO}_{2}\right]$ rich atmospheres? An analysis of diurnal courses of $\mathrm{CO}_{2}$ uptake under free-air concentration enrichment (FACE). Global Change Biology, 10, 951962.

Lehmeier C.A., Schaufele R., Schnyder H. (2005) Allocation of reserve-derived and currently assimilated carbon and nitrogen in seedlings of Helianthus annuus under subambient and elevated $\mathrm{CO}_{2}$ growth conditions. New Phytologist, 168, 613-621.

Long S.P., Ainsworth E.A., Rogers A., Ort D.R. (2004) Rising atmospheric carbon dioxide: plants FACE to the future. Annual Review of Plant Biology, 55, 591628.

McConnaughay K.D.M., Coleman J.S. (1999) Biomass allocation in plants: ontogeny on optimality? A test along three resource gradients. Ecology, 80, 25812593.

Mitsutoshi K., Takayoshi K., Hiroyuki T., Yutaka M. (2005) Elevated $\mathrm{CO}_{2}$ and limited nitrogen nutrition can restrict excitation energy dissipation in photosystem II of Japanese white birch (Betula platyphylla var. japonica) leaves. Physiologia Plantarum, 125, 64 73.

NOAA-ESRL (2014) National Oceanic and Atmospheric Administration-Earth System Research Laboratory. Trends in carbon dioxide. ESRL Web Team (January 2014). Available from Esrl.noaa.gov

5 (accessed XX Xxxxxxxx 20XX).

Nogués S., Azcón-Bieto J. (2013) Potential of local bio-geoengineering to mitigate dangerous temperature increases in a global warming scenario. Journal of Earth Science and Climatic Change, 4, 143-146.
Nogués S., Baker N. (2000) Effects of drought on photosynthesis in Mediterranean plants grown under enhanced UV-B radiation. Journal of Experimental Botany, 51, 1309-1317.

Nogués S., Tcherkez G., Cornic G., Ghashghaie J. (2004) Respiratory carbon metabolism following illumination in intact French bean leaves using ${ }^{12} \mathrm{C} /{ }^{13} \mathrm{C}$ labelling. Plant Physiology, 136, 3245-3254.

Nogués S., Aljazairi S., Arias C., Sánchez E., Aranjuelo I. (2014) Two distinct plant respiratory physiotypes might exist which correspond to fast-growing and slow-growing species. Journal of Plant Physiology, 171, 1157-1163.

Pagani M., Freeman K.H., Arthur M.A. (1999) Late miocene atmospheric $\mathrm{CO}_{2}$ concentrations and the expansion of $\mathrm{C}_{4}$ grasses. Science, 285, 876-879.

Pardo A., Aranjuelo I., Biel C., Save R., Azcon-Bieto J., Nogués S. (2009) Effects of long-term exposure to elevated $\mathrm{CO}_{2}$ conditions in slow-growing plants using ${ }^{12} \mathrm{C}$-enriched $\mathrm{CO}_{2}$ labelling technique. Rapid Communications in Mass Spectrometry, 23, 282-290.

Pearson P.N., Palmer M.R. (2000) Atmospheric carbon dioxide concentrations over the past 60 million years. Nature, 406, 695-699.

Prentice I.C., Farquhar G.D., Fasham M.J.R., Goulden M.L., Heimann M., Jaramillo V.J., Kheshgi H.S., Le Quéré C., Scholes R.J., Wallace D.W.R. (2001) The carbon cycle and atmospheric carbon dioxide. In: Houghton J.T., Noguer M., Ding Y., van der Linden P.J., Griggs D.J., Dai X., Maskell K., Johnson C.A. (Eds), Climate change 2001: the scientific basis, contribution of working group I to the third assessment report of the intergovernmental panel on climate change. Cambridge University Press, New York, NY, USA, pp 183-238.

Reynolds M.P., Rajaram S., Sayre K.D. (1999) Physiological and genetic changes of irrigated wheat in the post-green revolution period and approaches for meeting projected global demand. Crop Science, 39, 1611-1621.

Robinson D. (2001) $\delta^{15} \mathrm{~N}$ as an integrator of the nitrogen cycle. Trends in Ecology \& Evolution, 16, 153162.

Sage R.F. (1994) Acclimation of photosynthesis to increasing atmospheric $\mathrm{CO}_{2}$ : the gas exchange perspective. Photosynthesis Research, 39, 351-368.

Sage R.F., Coleman J.R. (2001) Effects of low atmospheric $\mathrm{CO}_{2}$ on plants: more than a thing of the past. Trends in Plant Science, 6, 1360-1385.
Sage R.F., Reid C.D. (1992) Photosynthetic acclimation to subambient $\mathrm{CO}_{2}(20 \mathrm{~Pa})$ in the $\mathrm{C}_{3}$ annual Phaseolus vulgaris $\mathrm{L}$. Photosynthetica, 27, 605-617.

Schnyder H. (1993) The role of carbohydrate storage and redistribution in the source-sink relations of wheat and barley during grain filling - review. New Phytologist, 123, 233-245.

Schnyder H., Schaüfele R., Lötscher M., Gebbing T. (2003) Disentangling $\mathrm{CO}_{2}$ fluxes: direct measurements of mesocosm-scale natural abundance ${ }^{13} \mathrm{CO}_{2} /{ }^{12} \mathrm{CO}_{2}$ gas exchange, ${ }^{13} \mathrm{C}$ discrimination, and labelling of $\mathrm{CO}_{2}$ exchange flux components in controlled environments. Plant, Cell and Environment, 26, 1863-1874.

Tambussi E.A., Bort J., Guiamet J.J., Nogués S., Araus J.J. (2007) The photosynthetic role of ears in $C_{3}$ cereals. Metabolism, water use efficiency and contribution to grain yield. Critical Reviews in Plant Sciences, 26, 1-16.

Tcherkez G. (2010) Natural ${ }^{15} \mathrm{~N} /{ }^{14} \mathrm{~N}$ isotope composition in $\mathrm{C}_{3}$ leaves: are enzymatic isotope effects informative for predicting the ${ }^{15} \mathrm{~N}$-abundance in key metabolites? Functional Plant Biology, 38, 112.

Tcherkez G., Nogués S., Bleton J., Cornic G., Badeck F., Ghashghaie J. (2003) Metabolic origin of carbon isotope composition of leaf dark-respired $\mathrm{CO}_{2}$ in French Bean. Plant Physiology, 131, 237-244.

Thomas R.B., Strain B.R. (1991) Root restriction as a factor in photosynthetic acclimation of cotton seedlings grown in elevated carbon dioxide. Plant Physiology, 96, 627-634.

Urban O. (2003) Physiological impact of elevated $\mathrm{CO}_{2}$ concentration ranging from molecular to whole plant responses. Photosynthetica, 41, 9-20.

Vitousek P.M. (1994) Beyond global warming: ecology and global change. Ecology, 75, 1861-1876.

Ward J.K., Strain B.R. (1997) Effects of low and elevated $\mathrm{CO}_{2}$ partial pressure on growth and reproduction of Arabidopsis thaliana from different elevations. Plant, Cell and Environment, 20, 254260.

Ward J.K., Antonovics J., Thomas R.B., Strain B.R. (2000) Is atmospheric $\mathrm{CO}_{2}$ a selective agent on model $\mathrm{C}_{3}$ annuals? Oecologia, 123, 330-341.

Werner R.A., Brand W.A. (2001) Referencing strategies and techniques in stable isotope ratio analysis. Rapid Communications in Mass Spectrometry, 15, 501-519. 


\section{Author Query Form}

Journal: $\quad$ PLB

Article: $\quad 12280$

Dear Author,

During the copy-editing of your paper, the following queries arose. Please respond to these by marking up your proofs with the necessary changes/additions. Please write your answers on the query sheet if there is insufficient space on the page proofs. Please write clearly and follow the conventions shown on the attached corrections sheet. If returning the proof by fax do not write too close to the paper's edge. Please remember that illegible mark-ups may delay publication.

Many thanks for your assistance.

\begin{tabular}{|c|c|c|}
\hline Query reference & Query & Remarks \\
\hline 1 & $\begin{array}{l}\text { AUTHOR: Running title should not exceed a maximum of } 40 \text { characters. Please check } \\
\text { and provide a suitable short title to conform to the journal style. }\end{array}$ & \\
\hline 2 & $\begin{array}{l}\text { AUTHOR: Aranjuelo 2011a has been changed to Aranjuelo et al. 2011a so that this } \\
\text { citation matches the Reference List. Please confirm that this is correct. }\end{array}$ & \\
\hline 3 & $\begin{array}{l}\text { AUTHOR: Tables 3, 2, 1, } 4 \text { have been changed to Tables } 1,2,3,4 \text {. Similar changes are } \\
\text { made in text also. Please check. }\end{array}$ & \\
\hline 4 & $\begin{array}{l}\text { AUTHOR: Fuertes-Mendizabal et al. } 2010 \text { has not been included in the Reference List, } \\
\text { please supply full publication details. }\end{array}$ & \\
\hline 5 & $\begin{array}{l}\text { AUTHOR: Please provide Accessed date, month and year for reference NOAA-ESRL } \\
\text { (2014). }\end{array}$ & \\
\hline 6 & $\begin{array}{l}\text { AUTHOR: Research Papers are subject to a page charge at a rate of } € 125 \text { per page above } \\
\text { the 8-page limit (the first } 8 \text { pages are free of charge). Your article exceeds the page limit. } \\
\text { Please go to the journal website, download the Page Charge Form, fill it in and send it } \\
\text { to the Production Editor at plb@wiley.com indicating the paper number. (Please click } \\
\text { on the following link to download the form: http://onlinelibrary.wiley.com/journal/10. } \\
1111 /(\text { ISSN) } 1438-8677 / \text { homepage/PLB_Page_Charge_Form.pdf). }\end{array}$ & \\
\hline
\end{tabular}




\section{Please correct and return this set}

Please use the proof correction marks shown below for all alterations and corrections. If you wish to return your proof by fax you should ensure that all amendments are written clearly in dark ink and are made well within the page margins.

\begin{tabular}{|c|c|c|}
\hline Instruction to printer & Textual mark & Marginal mark \\
\hline Leave unchanged & ... under matter to remain & ( \\
\hline $\begin{array}{l}\text { Insert in text the matter } \\
\text { indicated in the margin }\end{array}$ & $h$ & $\begin{array}{l}\text { New matter followed by } \\
h \text { or } h \otimes\end{array}$ \\
\hline Delete & $\begin{array}{l}\text { I through single character, rule or underline } \\
\text { or }\end{array}$ & $\sigma$ or $\sigma / \otimes$ \\
\hline $\begin{array}{l}\text { Substitute character or } \\
\text { substitute part of one or } \\
\text { more word(s) }\end{array}$ & / through letter or & $\begin{array}{l}\text { new character / or } \\
\text { new characters / }\end{array}$ \\
\hline Change to italics & — under matter to be changed & $\leftarrow$ \\
\hline Change to capitals & $\equiv$ under matter to be changed & $\equiv$ \\
\hline Change to small capitals & $=$ under matter to be changed & $=$ \\
\hline Change to bold type & $\sim$ under matter to be changed & $\sim$ \\
\hline Change to bold italic & $\approx$ under matter to be changed & $\underline{s i n}$ \\
\hline Change to lower case & Encircle matter to be changed & $\not$ \\
\hline Change italic to upright type & (As above) & \\
\hline Change bold to non-bold type & (As above) & \\
\hline Insert 'superior' character & $\begin{array}{l}\text { I through character or } \\
K \text { where required }\end{array}$ & $\begin{array}{l}y^{\prime} \text { or } y \\
\text { under character } \\
\text { e.g. } y^{2} \text { or } y^{2}\end{array}$ \\
\hline Insert 'inferior' character & (As above) & $\begin{array}{l}\text { L } \\
\text { over character } \\
\text { e.g. } \hat{\imath}\end{array}$ \\
\hline Insert full stop & (As above) & $\odot$ \\
\hline Insert comma & (As above) & , \\
\hline Insert single quotation marks & (As above) & $\begin{array}{l}\dot{y} \text { or } \dot{X} \text { and/or } \\
\dot{y} \text { or } \dot{X}\end{array}$ \\
\hline Insert double quotation marks & (As above) & $\begin{array}{l}\ddot{y} \text { or } \ddot{y} \text { and/or } \\
\ddot{y} \text { or } \ddot{x}\end{array}$ \\
\hline Insert hyphen & (As above) & $1-1$ \\
\hline Start new paragraph & $\digamma$ & 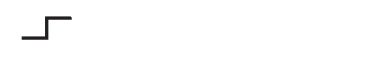 \\
\hline No new paragraph & $\infty$ & $\omega$ \\
\hline Transpose & $\sqcup$ & ᄃ \\
\hline Close up & linking $\bigcirc$ characters & \\
\hline $\begin{array}{l}\text { Insert or substitute space } \\
\text { between characters or words }\end{array}$ & $\begin{array}{l}\text { I through character or } \\
\Lambda \text { where required }\end{array}$ & \\
\hline $\begin{array}{l}\text { Reduce space between } \\
\text { characters or words }\end{array}$ & $\begin{array}{l}\text { between characters or } \\
\text { words affected }\end{array}$ & $\uparrow$ \\
\hline
\end{tabular}

